\title{
In situ observations and census of invasive mud crab Rhithropanopeus harrisii (Crustacea: Decapoda: Panopeidae) applied in the Black Sea and the Sea of Azov
}

\section{Наблюдения и учет in situ инвазивного краба Rbitbropanopeus barrisii (Crustacea: Decapoda: Panopeidae) в Черном и Азовском морях}

\author{
Anna K. Zalota*, Vassily A. Spiridonov, Galina A. Kolyuchkina \\ А.К. Залота*, В.А. Спиридонов, Г.А. Колючкина \\ P. Shirshov Institute of Oceanology, Russian Academy of Sciences, Nakhimovsky Prospekt, 36, Moscow, 117997, Russia. \\ *Corresponding author. E-mail: azalota@gmail.com \\ Институт океанологии им. П.П. Ширшова РАН, Нахимовский проспект, 36, Москва, 117997 Россия. \\ *Автор, которому должна быть адресована корреспонденция. E-mail: azalota@gmail.com
}

KEY WORDS: Invasive species, population size structure, habitat, estuary, hiding habit, Taman Bay, Krasnodar Area, Crimea.

КЛЮЧЕВЫЕ СЛОВА: Инвазивный вид, размерная структура популяции, местообитание, эстуарий, использование укрытий, Таманский залив, Краснодарский край, Крым.

ABSTRACT. Coastal areas, lagoons and river estuaries along the Crimean peninsula, Sea of Azov and Russian Krasnodar region Black Sea coast have been searched for the presence of Harris mud crab [Rhithropanopeus harrisii (Gould, 1841)] using snorkeling and SCUBA equipment. New populations were observed in 2 river estuaries (Vulan and Shap'sukho), Bugas liman adjacent to the Black Sea and it was widespread in the Taman Bay in the Sea of Azov. The crabs have been found in very distinct habitats from shallows of the Taman Bay with broad Zostera spp. meadows, to narrow reed roots bands along the river estuaries. Similar habitats between the Black and Azov seas have shown complete absence of the crab in one and presence in the other respectively. Our results show that currently no standard method that exists, can be applied to all different types of habitats that we observed in this study. Nevertheless, the method of underwater transect census allowed us to perform quantitative analysis of crabs' hiding behavior in the Taman Bay; smaller crabs of both sexes and most of ovigerous females prefer to hide in burrows. Size composition of crabs has been described for the Taman Bay and Black Sea estuary crab populations. These studies lead us to suppose that there is a seasonal migration pattern of $R$. harrisii in the shallows of the Taman Bay and no such observations are apparent in the estuary habitat. While distribution of different age groups and migration patterns may be very different, the general life cycle of Harris mud crab in these populations appears to be similar.

РЕЗЮМЕ. Прибрежные участки, лагуны и эстуарии рек вдоль побережья Крыма, Азовского моря и краснодарского побережья Черного моря были обследованы с помощью подводного снаряжения с целью нахождения Rhithropanopeus harrisii (Gould, 1841). Не известные ранее популяции были обнаружены в эстуариях рек Вулан и Шапсухо и Бугазском лимане Краснодарского края. Крабы обитают в самых различных местообитаниях от мелководий Таманского залива с подводными лугами Zostera spp. до узких полос зарослей тростника в речных эстуариях. Сходные местообитания в Черном и Азовском морях характеризовались отсутствием вида в первом и присутствием во втором. Длительные популяционные исследования проведены в Таманском заливе с целью разработки количественного метода сбора крабов. Наши результаты показывают, что такого единого метода, который можно было бы предложить для всех исследованных местообитаний, пока не существует. Тем не менее, использованный метод подводного трансектного учета позволил провести количественный анализ использования крабами укрытий: крабы более мелкого размера и большинство яйценосных самок тяготеют к пребыванию в норках и других укрытиях. Для популяций Таманского залива и эстуариев черноморского побережья описана размерная структура. Это исследование позволяет предполагать наличие сезонных миграций $R$. harrisii на мелководьях Таманского залива; наблюдения, подтверждающие аналогичное явления у крабов в эстуариях рек отсутствуют. В то время как распределение различных возрастных групп и их миграционная активность в этих популяциях отличается, общие черты жизненного цикла краба Харриса представляются сходными. 


\section{Introduction}

A small mud crab Rhithropanopeus harrisii (Gould, 1841) or Harris mud crab originates from the eastern coast of American continent, from New Brunswick to northern Mexico [Williams, 1984]. In the native distribution range it is generally associated with tidal estuaries where larvae of $R$. harrisii can maintain their distribution in estuarine areas by a complex mechanism of hatching synchronization with the tidal cycle and vertical migration superimposed to differences in velocity and directions of tidal flow [Forward, 2009 and references therein].

$R$. harrisii has invaded multiple basins around the world on almost all continents. In Europe (Fig. 1A), this mud crab species has been observed for the first time in 1874, in Zuiderzee, Netherlands [Maitland, 1874; Buitendijk, Holthuis, 1949]. Since then it has spread along river estuaries and bays of the North Europe [Reznichenko, 1967; Van der Velde et al., 2000; Kerckhof, 2001; Olesen, Tendal, 2009], but only recently populations of this species were found in Lithuania [Bacevièius, Gasiûnaitë, 2008], Estonia [Kotta, Ojaveer, 2012], and Finland [Karhilahti, 2010; Fowler et al., 2013]. It has spread further south along the Atlantic coast of Europe [Eno et al., 1997; Mariscal et al., 1991; Cuesta et al., 1991; Projecto-Garcia et al., 2010] and in to the Mediterranean [Mizzan, Zanella, 1996; Noël, 2001; Ben Souissi et al., 2004].

In the Black Sea $R$. harrisii has been found in the Dnieper and Bug estuaries in 1937, much earlier than in the Mediterranean [Makarov, 1939]. It had then spread to several neighboring estuaries, and around 1954-1957, Harris mud crab was reported from the open north-western Black Sea around Odessa [Reznichenko, 1967]. Simultaneously it was found throughout the Romanian and Bulgarian coasts [Zemiankowski, 1951; Marchand, Saudray, 1971]. Along the Crimean coast of the Black Sea it has only been reported from the Sevastopol Bay [Shalovenkov, 2005]. In the Sea of Azov Harris mud crab was first observed in the Taganrog Bay in 1948 [Mordukhay-Boltovskoy, 1952].
By 1950s this crab became a common species throughout this sea [Reznichenko, 1967]. Consequently R. harrisii penetrated further eastward and became abundant in the Caspian Sea presumably through the Don-Volga Canal [Nebolsina, 1959; Reznichenko, 1967] and was then unintentionally introduced to the Aral Sea [Andreev, Andreeva, 1988].

Surprisingly, so far, this species has not been reported in the published sources from the Taman Bay on the boundary of the Black and Azov seas, nor from the eastern Black Sea [except larvae found in some harbors, i.e. Selifonova, 2012]. The lack of data from such an extensive area in close vicinity to the old area of invasion limits precise mapping of Harris mud crab distribution in the north-eastern Europe and restricts our understanding of its ways of establishing new populations and the adaptive potential of this invasive species.

Most studies that have looked at distribution and ecology of $R$. harrisii, have done so by collecting crabs using bottom dredges [i.e. Ryan, 1956; Turoboisky, 1973; Hegele-Drywa et al., 2014] and exposing crates at long time within natural substrate [i.e. Roche, Torchin, 2007; Fowler et al.,2013]. In the Black Sea these methods are difficult to apply for rapid survey of an extensive area. Benthic substrates in the coastal zone are unsuited for dredging (i.e. rock, gravel or dense macrophytes beds) while long time setting of crates is impossible for most shores due to high exposure to wave impact. We therefore applied a methodology of in situ observations and underwater transect censuses, which in various versions is used in studies of commercial crab species [Miljutin, 2005].

The purpose of this study is the following: 1) to document occurrence of $R$. harrisii and its habitat preference along the Crimean Peninsula, the boundary area between the Sea of Azov and the Black Sea and along the eastern coast of the Black Sea; 2) to test the application of direct transect census for studying population dynamics of this species; 3) to characterize local aspects of sex and size composition of the sampled populations; 4) to describe the behavior and habitat preferences of the Harris mud crab in studied areas.

Fig. 1. Distribution of Rhithropanopeus harrisii: A. Historical findings of Rhithropanopeus harrisii in Europe. For sources see text. Diamond - area of initial introduction in European waters in the XIX century; circles - areas where Rhithropanopeus harrisii crab has been found; Hashed rectangle - area of the present study. B. Black Sea and Sea of Azov regions where R. harrisii has been searched in the present study. Circles - spots searched, but no $R$. harrisii has been found; stars $-R$. harrisii has been found; dashed rectangles - data from these regions has been used for population size structure analysis in this study; grey region $-R$. harrisii has been known from this area previous to this study; square — recent records by other authors; 1 - Tarkhankut peninsula, 2 - Kerch, 3 - Cape Zheleznyi Rog, 4 Anapa, 5 - Dyurso river, 6 - Yashamba river, 7 - Nechep'sukho river, 8 - Tuapse [Selifonova, 2012], 9 - Shepsi river, 10 Matrosskaya river, 11 - Uch-Dere, 12 - Khosta. C. Study area in the Taman Bay, Sea of Azov. Numerated circles - stations of the benthic survey in 2008; empty circles - records of small juveniles of $R$. harrisii; filled circles - no crabs have been found; star - main area of yearly observations in transects in summers 2011-2014.

Рис. 1. Распространение Rhithropanopeus harrisii в Европе: А. Исторические находки вида в Европе. Источники указаны в тексте. Ромб - район первоначального вселения в европейские воды в XIX веке: круги - районы, где R. harrisii был найден впоследствии; заштрихованный прямоугольник - район данного исследования. В. Места поиска Rhithropanopeus harrisii в Черном и Азовском морях в ходе данного исследования. Круги - обследованные районы, где краб Харриса не обнаружен; звездочки - районы находок краба Харриса; заштрихованная область - данные из этих мест были использованы для анализа размерной состава краба Харриса; районы с серой заливкой — краб был известен из этих районов ранее; квадрат - участок недавней находки другими авторами; 1 - Мыс Тарханкут, 2 - Керчь, 3 - Мыс Зеленый Рог, 4 - Анапа, 5 - река Дюрсо, 6 Река Яшамба, 7 - река Нечепсухо, 8 - Туапсе [Selifonova, 2012], 9 - река Шепси, 10 - река Матросская, 11 - Уч-Дере, 12 Хоста. С. Район исследований в Таманском заливе Азовского моря. Пронумерованные круги - бентосные станции 2008 г. (светлые круги - краб был обнаружен, темные круги - краб не был обнаружен); звездочка — основное место трансектных учетов крабов в летний сезон 2011-2014 гг. 
Material and methods

\section{Study areas}

We have searched for the presence of Rhithropanopeus harrisii in rivers and bays along the Black and Azov seas' shores of the Crimean Peninsula and in
Krasnodar Region of Russia and the Taman Bay. (Fig. 1B, Table 1). Only habitats where the Harris mud crab has been found are described further. For details of other spots see Table 1 .

Black Sea. The Bugas liman (Table 1; Fig. 1B) is a polyhaline (salinity $22 \%$ ) lagoon separated from the Black Sea by a narrow sandy strip and has a very
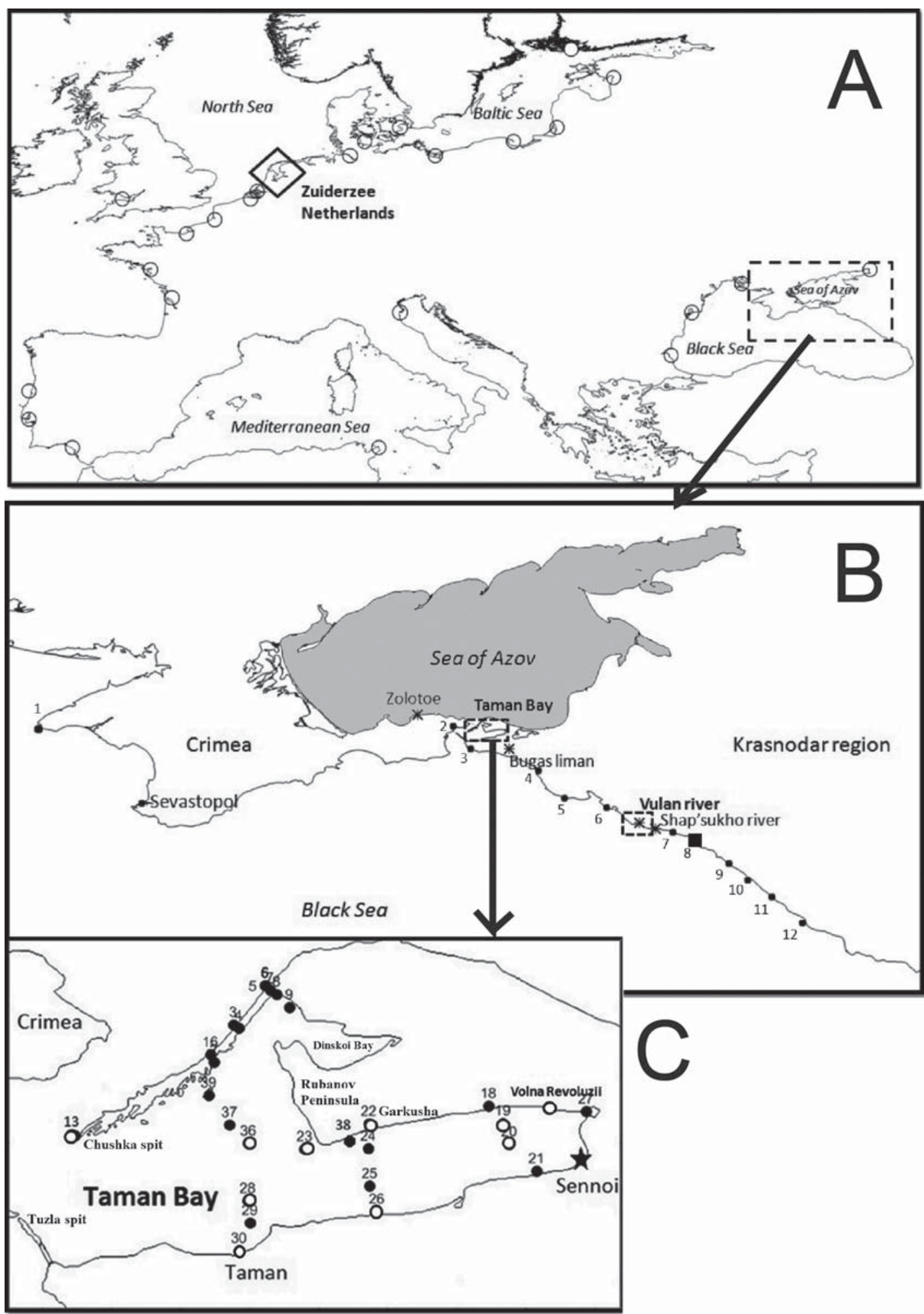
Table 1. List of studied localities in the Black Sea and the Sea of Azov.

Таблица 1. Перечень обследованных участков в Черном и Азовском морях.

\begin{tabular}{|c|c|c|c|c|c|c|c|}
\hline Sea & Region & Spot, depth & Position & Year & $\begin{array}{c}R . \\
\text { harrisii } \\
\text { found }\end{array}$ & $\begin{array}{l}\text { Other crab } \\
\text { species }\end{array}$ & Notes \\
\hline Black Sea & Crimea & $\begin{array}{l}\text { Sevastopol bay, } \\
0-5 \mathrm{~m}\end{array}$ & $\begin{array}{l}\text { N } 44^{\circ} 36^{\prime} 36.46^{\prime \prime}, \\
\text { E } 33^{\circ} 35^{\prime} 46.64\end{array}$ & Jun 2012 & No & $\begin{array}{l}\text { Pilumnus } \\
\text { hirtellus }\end{array}$ & $\begin{array}{l}\text { Closed bay; } \\
\text { mud, sand and } \\
\text { shell }\end{array}$ \\
\hline Black Sea & Crimea & $\begin{array}{l}\text { Sevastopol } \\
\text { Chernaya river, } \\
0-3 \mathrm{~m}\end{array}$ & $\begin{array}{l}\text { N } 44^{\circ} 35^{\prime} 53.67^{\prime \prime}, \\
\text { E } 33^{\circ} 36^{\prime} 26.98^{\prime \prime}\end{array}$ & Jun 2012 & No & Not recorded & $\begin{array}{l}\text { Closed inlet; } \\
\text { mud, shell and } \\
\text { stones; } \\
\text { indications of } \\
\text { significant } \\
\text { eutrophication }\end{array}$ \\
\hline Black Sea & Crimea & $\begin{array}{l}\text { Sevastopol shore, } \\
0-10 \mathrm{~m}\end{array}$ & Multiple places & Jun 2012 & No & \multirow{2}{*}{$\begin{array}{l}\text { Eriphia } \\
\text { verrucosa, } \\
\text { Liocarcinus } \\
\text { vernalis, } P \text {. } \\
\text { hirtellus }\end{array}$} & $\begin{array}{l}\text { Variety of } \\
\text { habitats }\end{array}$ \\
\hline Black Sea & Crimea & $\begin{array}{l}\text { Tarkhankut } \\
\text { peninsula, } 0-5 \mathrm{~m}\end{array}$ & $\begin{array}{l}\text { N } 45^{\circ} 19^{\prime} 58.76^{\prime \prime}, \\
\text { E } 32^{\circ} 33^{\prime} 21.84^{\prime \prime}\end{array}$ & Jun 2012 & No & & $\begin{array}{l}\text { Open shore; } \\
\text { pebble and } \\
\text { rocky substrates }\end{array}$ \\
\hline Black Sea & $\begin{array}{l}\text { Krasnodar } \\
\text { Region } \\
\text { (Novomikhai- } \\
\text { lovskiy*) }\end{array}$ & $\begin{array}{l}\text { Nechep'sukho } \\
\text { river; 0-1.5 m }\end{array}$ & $\begin{array}{l}\text { N } 44^{\circ} 14^{\prime} 34.77^{\prime \prime}, \\
\text { E } 38^{\circ} 50^{\prime} 12.82^{\prime \prime}\end{array}$ & Jul 2013 & No & Not recorded & $\begin{array}{l}\text { There was } \\
\text { flooding event } \\
\text { in } 2012 \text {, which } \\
\text { dramatically } \\
\text { changed the } \\
\text { banks of the } \\
\text { river; most of } \\
\text { the reed } \\
\text { overgrowth and } \\
\text { soft sediments } \\
\text { have been } \\
\text { flushed out; } \\
\text { salinity } 4 \%\end{array}$ \\
\hline Black Sea & $\begin{array}{l}\text { Krasnodar } \\
\text { Region } \\
(\text { Lermontovo *) }\end{array}$ & $\begin{array}{l}\text { Shap'sukho } \\
\text { river** , 0-2 m }\end{array}$ & $\begin{array}{l}\text { N } 44^{\circ} 18^{\prime} 13.40^{\prime \prime}, \\
\text { E } 38^{\circ} 44^{\prime} 38.40^{\prime \prime}\end{array}$ & $\begin{array}{l}\text { Aug 2012, } \\
\text { Jul } 2013\end{array}$ & Yes & Not recorded & \multirow{3}{*}{$\begin{array}{l}\text { See text for } \\
\text { details }\end{array}$} \\
\hline Black Sea & $\begin{array}{l}\text { Krasnodar } \\
\text { Region } \\
(\text { Arkhipo- } \\
\text { Osipovka *) }\end{array}$ & $\begin{array}{l}\text { Vulan river, } \\
0-1.5 \mathrm{~m}\end{array}$ & $\begin{array}{l}\text { N } 44^{\circ} 21^{\prime} 51.40^{\prime \prime}, \\
\text { E } 38^{\circ} 31^{\prime} 17.75^{\prime \prime}\end{array}$ & $\begin{array}{l}\text { Aug 2012, } \\
\text { Jul } 2013\end{array}$ & Yes & Not recorded & \\
\hline Black Sea & $\begin{array}{l}\text { Krasnodar } \\
\text { Region } \\
\text { (Blagoveshchen- } \\
\text { skaya*) }\end{array}$ & $\begin{array}{l}\text { Bugas liman, } \\
0-2 \mathrm{~m}\end{array}$ & $\begin{array}{l}\text { N } 45^{\circ} 3^{\prime} 53.52^{\prime \prime}, \\
\text { E } 37^{\circ} 2^{\prime} 21.07^{\prime \prime}\end{array}$ & Jun 2014 & Yes & Not recorded & \\
\hline Black Sea & $\begin{array}{l}\text { Krasnodar } \\
\text { Region } \\
\text { (Blagoveshchen- } \\
\text { skaya*) }\end{array}$ & $\begin{array}{l}\text { Bugas peninsula } \\
\text { sea shore, } 0-5 \mathrm{~m}\end{array}$ & $\begin{array}{l}\text { N } 45^{\circ} 3^{\prime} 53.52^{\prime \prime}, \\
\text { E } 37^{\circ} 2^{\prime} 21.07^{\prime \prime}\end{array}$ & $\begin{array}{l}\text { Aug 2012, } \\
\text { Jul 2013, } \\
\text { June 2014 }\end{array}$ & No & $\begin{array}{l}\text { Brachynotus } \\
\text { sexdentatus** } \\
*, \text { Carcinus } \\
\text { aestuarii, L. } \\
\text { vernalis, } P . \\
\text { hirtellus, } \\
\text { Macropodia } \\
\text { czernjawskii, } \\
\text { Xantho } \\
\text { poressa, }\end{array}$ & $\begin{array}{l}\text { Open shore } \\
\text { areas dominated } \\
\text { by sandy } \\
\text { beaches and } \\
\text { extensive } \\
\text { shallow sandy } \\
\text { areas. At } \\
\text { approximately } \\
2-5 \text { meter depth } \\
\text { there is a sandy } \\
\text { bottom with } \\
\text { crushed shell } \\
\text { debris and } \\
\text { patches of } \\
\text { filamentous } \\
\text { algae }\end{array}$ \\
\hline Black Sea & $\begin{array}{l}\text { Krasnodar } \\
\text { Region } \\
(\text { Anapa } *)\end{array}$ & $0-4 \mathrm{~m}$ & $\begin{array}{l}\text { N } 44^{\circ} 53^{\prime} 55.09^{\prime \prime} \\
\text { E } 37^{\circ} 18^{\prime} 48.14^{\prime \prime}\end{array}$ & Aug 2012 & No & Not recorded & $\begin{array}{l}\text { Open sandy and } \\
\text { pebble beach, } \\
\text { indications of } \\
\text { strong } \\
\text { eutrophication }\end{array}$ \\
\hline Black Sea & $\begin{array}{l}\text { Krasnodar } \\
\text { Region } \\
(\text { Volna } *)\end{array}$ & $\begin{array}{l}\text { Near cape } \\
\text { Zheleznii Rog, } \\
0-3 \mathrm{~m}\end{array}$ & $\begin{array}{l}\text { N } 45^{\circ} 6^{\prime} 50.56^{\prime \prime}, \\
\text { E } 36^{\circ} 45^{\prime} 0.83^{\prime \prime}\end{array}$ & Aug 2012 & No & $\begin{array}{l}\text { E. verrucosa, } \\
\text { L. vernalis, } \\
\text { M. } \\
\text { czernjawskii, } \\
\text { P. hirtellus }\end{array}$ & $\begin{array}{l}\text { Clay cliffs and } \\
\text { benches with } \\
\text { reefs (with } \\
\text { bores of a rock- } \\
\text { boring mollusk } \\
\text { Pholas } \\
\text { dactylus) }\end{array}$ \\
\hline
\end{tabular}


Table 1 (contituing)

Таблица 1 (продолжение)

\begin{tabular}{|c|c|c|c|c|c|c|c|}
\hline Black Sea & $\begin{array}{l}\text { Krasnodar } \\
\text { Region } \\
\text { (Khosta *) }\end{array}$ & $0-2 \mathrm{~m}$ & $\begin{array}{l}\text { N } 43^{\circ} 30^{\prime} 46.41^{\prime \prime} \\
\text { E } 39^{\circ} 51^{\prime} 35.51^{\prime \prime}\end{array}$ & Aug 2012 & No & \multirow{6}{*}{$\begin{array}{l}\text { E. verrucosa, } \\
\text { Pachygrapsus } \\
\text { marmoratus }\end{array}$} & \multirow{6}{*}{$\begin{array}{l}\text { Open rocky } \\
\text { shore } \\
\text { intermitted by } \\
\text { pebble beaches; } \\
\text { rivers with } \\
\text { poorly } \\
\text { developed } \\
\text { estuaries }\end{array}$} \\
\hline Black Sea & $\begin{array}{l}\text { Krasnodar } \\
\text { Region } \\
(\text { Uch-Dere *) } \\
\end{array}$ & $0-2 \mathrm{~m}$ & $\begin{array}{l}\text { N } 43^{\circ} 39^{\prime} 54.76^{\prime \prime}, \\
\text { E 39 } 36^{\prime} 50.98^{\prime \prime}\end{array}$ & Aug 2012 & No & & \\
\hline Black Sea & $\begin{array}{l}\text { Krasnodar } \\
\text { Region } \\
(\text { Golovinka } *)\end{array}$ & $\begin{array}{l}\text { Matrosskaya } \\
\text { river**, 0-2 m }\end{array}$ & $\begin{array}{l}\text { N } 43^{\circ} 48^{\prime} 0.05^{\prime \prime} \\
\text { E } 39^{\circ} 27^{\prime} 12.10^{\prime \prime}\end{array}$ & Aug 2012 & No & & \\
\hline Black Sea & $\begin{array}{l}\text { Krasnodar } \\
\text { Region } \\
(\text { Shepsi *) }\end{array}$ & $\begin{array}{l}\text { Shepsi river**, } \\
0-2 \mathrm{~m}\end{array}$ & $\begin{array}{l}\text { N } 44^{\circ} 1 ' 59.71 ", \\
\text { E } 39^{\circ} 8^{\prime} 30.85^{\prime \prime}\end{array}$ & Aug 2012 & No & & \\
\hline Black Sea & $\begin{array}{l}\text { Krasnodar } \\
\text { Region } \\
\text { (Gelendzjik *) }\end{array}$ & $\begin{array}{l}\text { Yashamba river } \\
* *, 0-2 \mathrm{~m}\end{array}$ & $\begin{array}{l}\text { N } 44^{\circ} 34^{\prime} 30.83^{\prime \prime} \\
\text { E } 37^{\circ} 58^{\prime} 43.97^{\prime \prime}\end{array}$ & Aug 2012 & No & & \\
\hline Black Sea & $\begin{array}{l}\text { Krasnodar } \\
\text { Region } \\
(\text { Dyurso *) }\end{array}$ & $\begin{array}{l}\text { Dyurso river**, } \\
0-2 \mathrm{~m}\end{array}$ & 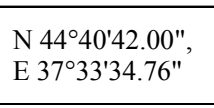 & Aug 2012 & No & & \\
\hline $\begin{array}{l}\text { Sea of } \\
\text { Azov }\end{array}$ & Crimea & Kerch* & $\begin{array}{l}\text { N } 45^{\circ} 19^{\prime} 16.15^{\prime \prime} \\
\text { E } 36^{\circ} 28^{\prime} 52.40^{\prime \prime}\end{array}$ & Jun 2012 & No & Not recorded & $\begin{array}{l}\text { Bad weather } \\
\text { conditions } \\
\text { during survey }\end{array}$ \\
\hline $\begin{array}{l}\text { Sea of } \\
\text { Azov }\end{array}$ & Crimea & Zolotoe*, 0-2 m & $\begin{array}{l}\text { N } 45^{\circ} 26^{\prime} 37.17 " \\
\text { E } 36^{\circ} 44^{\prime} 31.66^{\prime \prime}\end{array}$ & Jun 2012 & Yes & Not recorded & $\begin{array}{l}\text { See text for } \\
\text { details }\end{array}$ \\
\hline $\begin{array}{l}\text { Sea of } \\
\text { Azov }\end{array}$ & $\begin{array}{l}\text { Krasnodar } \\
\text { Region }\end{array}$ & $\begin{array}{l}\text { Beysug Liman, } \\
0-1 \mathrm{~m}\end{array}$ & $\begin{array}{l}\text { N } 46^{\circ} 9^{\prime} 13.09^{\prime \prime} \\
\text { E } 38^{\circ} 28^{\prime} 1.50^{\prime \prime}\end{array}$ & Aug 2012 & No & Not recorded & $\begin{array}{l}\text { Shallow area } \\
\text { with extensive } \\
\text { reed coverage }\end{array}$ \\
\hline $\begin{array}{l}\text { Taman } \\
\text { Bay }\end{array}$ & $\begin{array}{l}\text { Krasnodar } \\
\text { Region }\end{array}$ & $0-4 \mathrm{~m}$ & $\begin{array}{l}\text { Multiple spots on } \\
\text { the coast and } \\
\text { inside the bay }\end{array}$ & $\begin{array}{l}\text { March } \\
2008 \\
\text { Jul 2008 } \\
\text { Jul 2011 } \\
\text { Aug 2012 } \\
\text { Jul 2013 } \\
\text { Apr 2014 } \\
\text { Jun 2014 } \\
\end{array}$ & Yes & P. hirtellus & \\
\hline $\begin{array}{l}\text { Taman } \\
\text { Bay }\end{array}$ & $\begin{array}{l}\text { Krasnodar } \\
\text { Region } \\
\text { (Sennoi *) }\end{array}$ & $\begin{array}{l}\text { Coastal shallows } \\
\text { in inner part of } \\
\text { bay, } 0-2 \mathrm{~m}\end{array}$ & $\begin{array}{l}\text { N } 45^{\circ} 16^{\prime} 43.09^{\prime \prime} \\
\text { E } 36^{\circ} 57^{\prime} 45.28^{\prime \prime}\end{array}$ & $\begin{array}{l}\text { Jul } 2008 \\
\text { Jul } 2011 \\
\text { Aug } 2012 \\
\text { Jul } 2013 \\
\text { Apr } 2014 \\
\text { Jun } 2014 \\
\end{array}$ & Yes & P. hirtellus & $\begin{array}{l}\text { See text for } \\
\text { details }\end{array}$ \\
\hline $\begin{array}{l}\text { Taman } \\
\text { Bay }\end{array}$ & $\begin{array}{l}\text { Krasnodar } \\
\text { Region }\end{array}$ & $\begin{array}{l}\text { Rubanov } \\
\text { Peninsula, } 0-2 \mathrm{~m}\end{array}$ & $\begin{array}{l}\text { N 4519'28.77", } \\
\text { E 36²47'9.67" }\end{array}$ & Jul 2013 & Yes & P. hirtellus & \\
\hline $\begin{array}{l}\text { Taman } \\
\text { Bay }\end{array}$ & $\begin{array}{l}\text { Krasnodar } \\
\text { Region } \\
(\text { Taman *) } \\
\end{array}$ & $0-2 \mathrm{~m}$ & $\begin{array}{l}\text { N } 45^{\circ} 13^{\prime} 18.53^{\prime \prime} \\
\text { E } 36^{\circ} 44^{\prime} 31.53^{\prime \prime}\end{array}$ & Jul 2013 & Yes & P. hirtellus & \\
\hline $\begin{array}{l}\text { Taman } \\
\text { Bay }\end{array}$ & $\begin{array}{l}\text { Krasnodar } \\
\text { Region }\end{array}$ & Tuzla spit, $0-3 \mathrm{~m}$ & $\begin{array}{l}\text { N } 45^{\circ} 14^{\prime} 40.91 ", \\
\text { E } 36^{\circ} 35^{\prime} 28.98^{\prime \prime}\end{array}$ & $\begin{array}{l}\text { Jul 2009, } \\
\text { Aug } 2012\end{array}$ & Yes & Not recorded & \\
\hline $\begin{array}{l}\text { Taman } \\
\text { Bay }\end{array}$ & $\begin{array}{l}\text { Krasnodar } \\
\text { Region } \\
\text { (Volna Revo- } \\
\text { lutsii *) }\end{array}$ & $\begin{array}{l}\text { Inner part of bay, } \\
0-2 \mathrm{~m}\end{array}$ & $\begin{array}{l}\text { N } 45^{\circ} 19^{\prime} 43.31 ", \\
\text { E } 36^{\circ} 55^{\prime} 50.08^{\prime \prime}\end{array}$ & Jul 2013 & Yes & Not recorded & \\
\hline
\end{tabular}

Legend: * Villages/Towns, ** Both river estuary and nearby sea shore has been searched. *** first record of the species in this region of the Black Sea. See Figures 1 B,C

narrow canal that connects these two water bodies. It is very shallow and has soft bottom sediments covered by a thick bacterial mat. There are sporadic patches of macrophytes and large numbers of Idotea balthica and Cerastoderma glaucum.

Estuaries of major rivers along the shore of the Black Sea in Krasnodar region, Russia have been inspected. Most of these rivers are subject to large flooding events during the rainy season, and very low water levels in summer and near 0\% salinity. Rivers Shap'sukho near Lermontovo village and Vulan near Arkhipo-Osipovka village (Table 1; Fig. 1B) are subject to less flooding during rain. Estuaries of these rivers unlike most others have muddy shores and a lower flow speed which allows salty water to enter from the sea raising their salinity levels up to $9 \%$. These rivers have reed growth along its shore and islands. 
Sea of Azov. An open shore near village Zolotoe on the Sea of Azov side of the Crimean Peninsula (Table 1; Fig. 1B) is subject to high wave impact. Sediments were mostly crushed shell debris and stones, with sparse macrophyte vegetation (Fig. 2A).

Taman Bay. The Taman Bay is formally included in the Sea of Azov, but it has a distinct hydrological regime. It became a regular area of study (between 2008 and 2014) after the black oil spill in the Kerch Strait in November 2007 [see Kolyuchkina et al., 2008, 2009, 2012] (Fig. 1C). This bay is a large (about 350 $\mathrm{km}^{2}$ ), shallow (maximum depth does not exceed $5 \mathrm{~m}$ ) embayment which opens to the Kerch Strait in the south-western part of the Sea of Azov. In the western part it is separated from the Kerch Strait by Chushka spit and in the south by Tuzla spit which has been artificially extended and strengthened in mid-2000s. The bay lacks freshwater continental discharge; its sea level and hydrological regime are strongly influenced by dominating winds. Temperature may rise up to 27 $28^{\circ} \mathrm{C}$ (and even up to $32^{\circ} \mathrm{C}$ as we have observed in shallow areas in 2009) in summer and fall, to a freezing point in winter. Salinity in the bay usually ranges between 14.8 and $15.5 \%$, which is higher than the salinity of the southern Sea of Azov (10-11\%) [Zalogin, Kosarev, 1999; Golovkina, Nabozhenko, 2012]. Our measurements indicate that it may reach up to $18 \%$, if winds drive the Black Sea water inside the bay. A peculiar characteristic of the Taman Bay is the importance of macrophytes in the ecosystem and large shallow water areas.

Shallow zone near Sennoi village is very broad. Depth of $2 \mathrm{~m}$ is approximately 200 meters away from the shore (Fig. 1C). We have chosen this area for our study due to an easy access and its shallowness. Approximately $100 \mathrm{~m}$ away from the shore it is still an arm's length depth. This allowed us to collect crabs without any special equipment, just with a mask, to search thoroughly through the sediments as well as to observe crabs without scaring them with our movements. During weak wind conditions the water is clear and the majority of crabs can be visually spotted. In colder seasons strong winds can blow away large amounts of water resulting in open sediments of up to $50 \mathrm{~m}$ from the shore [pers. comm. local community, pers. observations by AZ]. Sediments in this zone are silty sands, mostly covered by macrophytes (Potamogeton sp., Zostera noltei, Cystoseira sp., green filamentous and brown algae) with patches of open sandy sediments. The top oxygenated layer is about $3 \mathrm{~cm}$ thick, below a dark, anoxic layer is present. Infaunal communities are dominated by cockle (Cerastoderma glaucum), another bivalve Loripes lucinalis and a gastropod Bittium reticulatum. For the epifauna, patches of blue mussels (Mytilus galloprovincialis), barnacles (Balanus improvisus) and sea anemones (Actiniaria, yet unidentified and probably an alien species; N. Sanamyan, pers. comm.) on available substrates are characteristic. Active benthic macrofauna mainly consists of Gammarus aequicauda, Idotea balthica, R. harrisii,
Palaemon adspersus; among benthic fishes gobies ( $G o$ bius spp.) and Sygnathus nigrolineatus are common. Deeper than approximately $2 \mathrm{~m}, Z$. noltei is substituted by eelagras meadows of Zostera marina. Deeper than $3.5-4 \mathrm{~m}$ seabed is dominated by muddy sediments with thick bacterial mats, rare patches of macrophyte vegetation, sea anemones and other sessile macrofauna sitting on dead cockle shells (underwater observations by the authors).

\section{Observations and collecting methods}

For short site visits along the Black and Azov seas' shores we used a standardized observation scheme. The non-estuary shore sites were usually surveyed within a day or two using SCUBA diving or snorkeling equipment from the watermark to the depth of 2-5 m (depending on the bottom topography). All underwater excursions were done during daytime and only if there was appropriate visibility. During the excursion we inspected all characteristic biotopes, carefully examining those where crabs could be hiding, i.e. stones, holes, crevices, macrophyte beds, fouling communities, artificial substrates and shore protection constructions.

In estuaries, where low visibility precluded underwater observation, we inspected shores, stones, litter, artificial substrates and reed plants using hand net and spade.

In the Taman Bay we used data of macrobenthic survey (conducted between 7 and 29 July 2008) to reveal distribution of juvenile Harris mud crabs. Samples have been taken using SCUBA diving equipment with manual tube sampler $\left(0.0095 \mathrm{~m}^{2}\right) ; 3$ to 5 casts at each station. (Fig. 1C) Samples have been washed through a $0.5 \mathrm{~mm}$ mesh, fixed with buffered $4 \%$ formaldehyde and later sorted in the laboratory.

Transect censuses in the Taman Bay have been conducted near village Sennoi. $R$. harrisii has been sampled in July 2011, August 2012, July 2013 and June 2014. Crabs have been collected from $100 \mathrm{~m}^{2}$ rectangular transect perpendicular to the shore. The first author walked 100 average steps away from the shore and swam back to the shore observing and collecting all crabs that were within $1 \mathrm{~m}$ reach around her. The maximum depth was at an arm's length (approximately $1 \mathrm{~m}$ ). The last half a meter, near the shore, was often omitted due to low visibility. The researcher, using snorkeling equipment and a wet suit, spent up to an hour passing one transect, depending on the quantity of crabs observed. All crabs that were not in burrows were placed in a separate sampling bag to those that were found in burrows. All large double or multiple burrows were poked with finger and crabs emerged from the opposite entrance. Roots of macrophytes were poked through with fingers in search for pockets where females might hide. In areas with substantial Zostera noltei coverage the grass has been "brushed" by hands. All empty bivalve shells and stones were overturned. Specimens from most sampling efforts in 2011 have been measured with a ruler on the shore and released. 

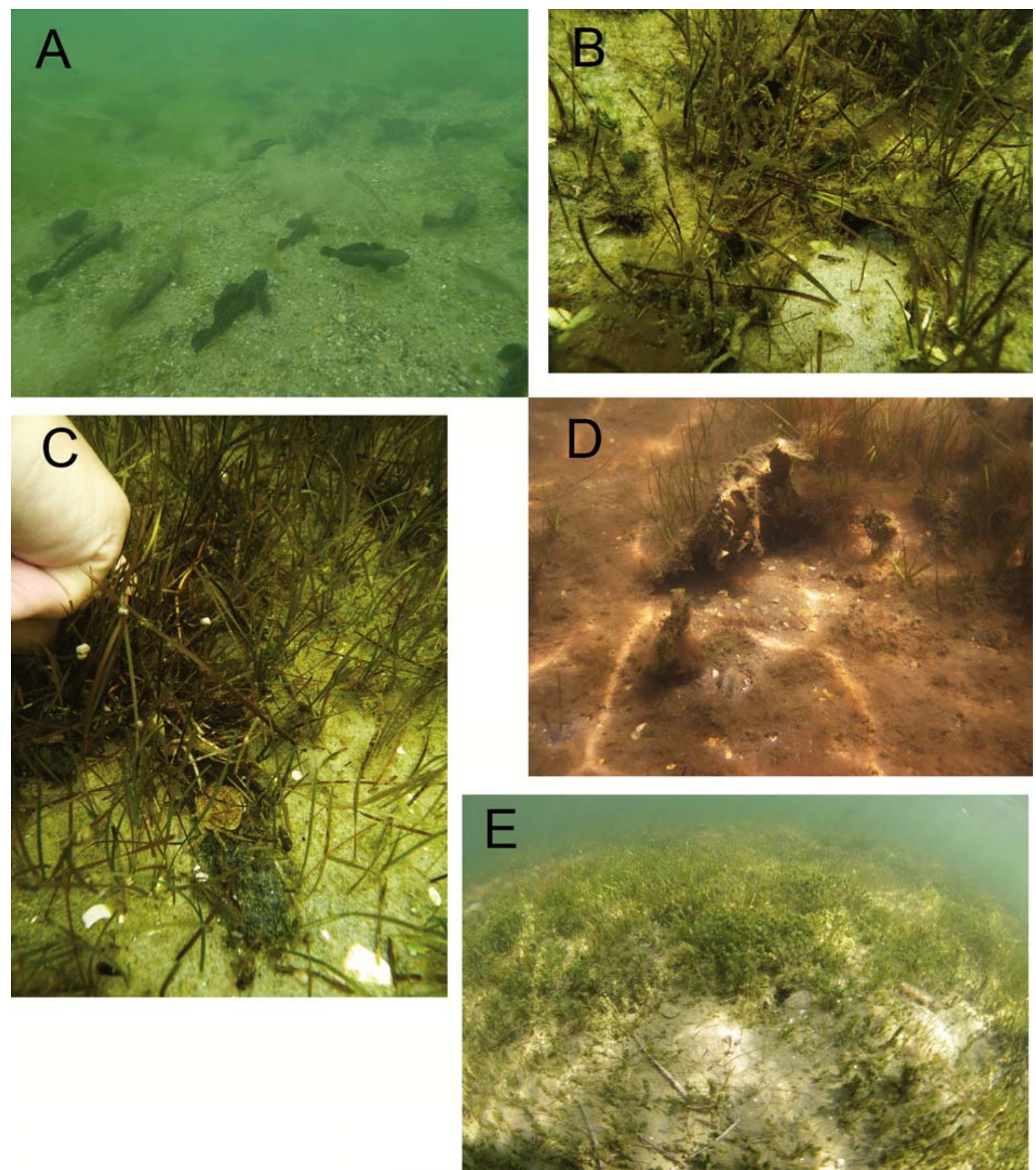

Fig. 2. Examples of habitats where Rhithropanopeus harrisii has been observed: A — sandy/shell debris habitat near the village Zolotoe, Sea of Azov. Crabs have been found hiding under some stones that were scattered on the bottom, with high density of gobies fish presence. B, C - burrows in the Zostera noltei medow near village Sennoi, Taman Bay, 2011. D - muddy sediments with thick bacterial mat in Bugas liman, near village Blagoveshchenskaya. E — patchy cover of macriphytes in the shallows near village Sennoi, Taman Bay in 2013.

Рис. 2. Примеры местообитаний Rhithropanopeus harrisii: А — песок и ракуша у пос. Золотое, Азовское море. Крабы были обнаружены под отдельными камнями; присутствовало большое количество бычков. В, С - норки в зарослях Zostera noltei у пос. Сенной, Таманский залив, в 2011 г. D - илистое дно с бактериальной пленкой в Бугаском лимане, у станицы Благовещенская. E - мозаичный покров макрофитов у пос. Сенной, Таманский залив, 2013 г.

In other years most of crabs have been fixed in $10 \%$ formaldehyde and transported to the laboratory. Crabs collected in August 2012 were not used in this study since no successful completion of a standard transect has been made due to high quantities of filamentous algae that restricted visibility.

In river estuaries crabs have been collected by cutting off parts of "root walls" created by reeds along the 
shore. Chunks of these roots have been detached with a spade directly into a bag, washed through and all crabs were picked out by hand.

\section{Analysis}

All crabs have been sexed, carapace width $(\mathrm{CW})$ has been measured with accuracy $0.2 \mathrm{~mm}$ using a caliper or a ruler (in 2011). For the analysis we used CW sizes of crabs collected by a standard method from the Taman Bay, near Sennoi village, juveniles found in the benthic 2008 Taman Bay samples and from river $\mathrm{Vu}-$ lan in Arkhipo-Osipovka, where the sampling method is likely to represent local population structure with low sampling error. To analyze population size structure, a mixing model analysis of $\mathrm{CW}$ sizes has been performed using PAST software package [version 3.0; Hammer, 2013]. The Akaike information criterion [Akaike, 1974] and the log likelihood parameter have been used to identify best fit model. The mixture model analysis has been re-run 50 times. All ANOVA tests have been performed using $\mathrm{R}$ software package [R Core Team, 2013].

\section{Results}

\section{Rhithropanopeus harrisii occurrence}

Black Sea

Crimean Peninsula. Site visits along the western coast of Crimea did not result in observations of Rhithropanopeus harrisii (Table 1).

The Black Sea coast in the Krasnodar region. No indications of $R$. harrisii presence in the open shore areas of Khosta, Uch-Dere, Golovinka, Shepsi, Gelendzhik, Dyurso, Anapa, Blagoveschenskaya, and Volna have been observed (Table 1; Fig. 1B).

In the Bugas liman (Table 1; Fig. 1B), R. harrisii were sitting on macrophyte beds, hid in the folds of bacterial mat and rarely in burrows which were scarce and mostly populated by gobies (Fig. 2D). As mentioned above, no $R$. harrisii have been observed in close vicinity to the liman on open shore area, although salinity in the liman was higher $(22.5 \%$ ) than that of the open sea (17\%o), or the Taman Bay (14.8-15.5\%o).

Rivers

Harris mud crabs have been found on an island in River Shap'sukho estuary (Table 1; Fig. 1B) overgrown by reed. Due to low visibility, we were only able to observe the very top layer of the island and no burrows have been observed. Crabs have been seen feeding on the overgrowth of submerged reeds. They were dark colored and hid at first sight of any movement. Only very small amount of specimens have been collected in August 2012 and no specimens have been caught in July 2013 although they have been spotted.

In the estuary of River Vulan (Table 1; Fig. 1B) Harris mud crabs have been found in rare shallow areas under stones. More commonly they have been collected from the roots of reeds along the shore. These roots created an abrupt wall with deep network of crevices where the crabs resided. All crabs were dark colored and hid at any sign of the collector's movement. Not much visual observations could be made due to very low visibility. Bottom sediments along these walls were very soft and bubbles of gas came out when pressed.

Taman Bay. During the underwater sampling and excursions, Harris mud crab has been spotted in most parts of the Taman Bay, i.e. in the coastal area of Tuzla spit, near Taman town, in the central deepest part, in the inner part near Sennoi, Volna Revolutsii and Garkusha villages at depth between 0 and $4 \mathrm{~m}$ (Table 1; Fig. 1C). It occurred in practically all kinds of habitats known there: sandy bottom with different amount of mud and shells and mosaic macrophyte vegetation and philamentous algae, in seagrass meadows, on clay reefs and patches with a labyrinth of crevices, in mussel beds, on muddy bottom with cockle shell and sparse macrophytes, and on stone blocks of the antique jetty exposed during underwater archaeological excavations by the Fanagorian Archaeological Expedition in Sennoi (Fig. 2B, C, E). Of particular interest are the early spring (8.03.2008) observations made in front of Sennoi where relatively numerous crabs have been observed at depth $3.2 \mathrm{~m}$ among cockles and sparse eelgrass on the grey-brown mud with a thin (about $1 \mathrm{~cm}$ ) upper light oxygenated layer and a thick dark anoxic layer under-laid by dense shell deposits. The only area where we have not spotted $R$. harrisii is the very shallow (usually less than $1.5 \mathrm{~m}$ ) north-western part of the Bay, in so called Dinskoi Bay and along the Chushka spit where extensive areas are occupied by reed [Spiridonov et al., 2016].

Small juvenile Harris mud crabs were practically absent in our hand-picked samples, while the benthic survey conducted in the Taman Bay in July 2008 in deeper areas (Fig. 1C) revealed them to be present at $30 \%$ of stations. They were however absent in the very shallow north-western part of the bay. In the eastern part of the Taman Bay their frequency of occurrence was $43 \%$. Small sizes of most crabs (see below) and the presence of megalopa larvae and early crab stages indicate that they recently passed metamorphosis and settled on the substrata. In most spots, where juvenile crab were present, sediments were muddy (alevropelite fraction exceeded 50\%) except stations 23 and 26 (Fig. 1C) where dense shell substrate has been observed. In half of these stations juvenile crabs settled in dense eelgrass meadows, in other cases seagrass was patchy but seabed was covered with green or brown algae. Macrobenthic biomass in all stations where crabs were present was high (217-1573 g per $\left.\mathrm{m}^{2}\right)$. Particularly high values have been observed for the communities dominated by Mytilaster lineatus, C. glaucum and Anadara kagoshimensis [Kolyuchkina et al., 2013]. At station 26, adult crabs along with numerous sea anemones have also been observed. Rough calculation indicate that the number of just settled mud crabs in eelgrass belt may be as high as 125-325 individuals per $\mathrm{m}^{2}$, but these figures have to be taken with caution 
Table 2. General information on standard transects for censuses of Rhitropanopeus harrisii in the Taman Bay, Sea of Azov in different years.

Таблица 2. Общая информация по стандартным трансектам, на которых проводиличь учеты Rhitropanopeus harrisii в разные года в Таманском заливе Азовского моря.

\begin{tabular}{|c|c|c|c|c|c|c|c|}
\hline GPS & Year & Salt & $\begin{array}{c}\text { Temp } \\
\text { C }^{\circ}\end{array}$ & $\begin{array}{c}\mathbf{N} \text { of } \\
\text { transects }\end{array}$ & $\begin{array}{l}\mathrm{N} \text { of } \\
\text { crabs }\end{array}$ & $\begin{array}{c}\text { Crab per } \\
\mathbf{m}^{2}\end{array}$ & Notes \\
\hline \multirow{5}{*}{$\begin{array}{l}\text { N } 5^{\circ} 16^{\prime} 43.09^{\prime \prime} \\
\text { E } 36^{\circ} 57^{\prime} 45.28^{\prime \prime}\end{array}$} & 10-18 Jul 2011 & 16,5 & & 8 & 1096 & 1,440 & \\
\hline & Aug 2012* & & & 0 & 20 & & $\begin{array}{l}\text { no visibility, high } \\
\text { content of } \\
\text { filamentous algae }\end{array}$ \\
\hline & $4-12$ Jul 2013** & 19,5 & 24 & 7 & 64 & 0,091 & $\begin{array}{l}\text { and } 3 \text { parallel } \\
\text { transects at } 1.5,2 \text { and } \\
3 \text { (no crabs found) } \\
\text { meter depths }\end{array}$ \\
\hline & $\begin{array}{l}\text { 20-25 April } \\
2014 *\end{array}$ & 17 & 19,5 & 6 & 20 & 0,033 & \\
\hline & 19-23 Jun 2014 & 17 & 23,5 & 4 & 21 & 0,053 & \\
\hline
\end{tabular}

Legend: * Not used in this paper, ** 5 standard and 2 parallel transects are used in this paper's analysis (no crabs found at 3 meter depth parallel transect).

owing to sampling constraints. In July 2011 we occasionally observed very small $R$. harrisii in eelgrass meadows at depth of about $2.5 \mathrm{~m}$ in front of Sennoi. A benthic survey of 15 stations, using the same methods and having even broader coverage than the survey of 2008, did not reveal presence of recently settled crabs in the Taman Bay in July 2013.

Pilumnus hirtellus (Linnaeus, 1761) is the only other brachyuran species found in the Taman Bay (Table 1). Near Taman town and in the vicinity of Rubanov Peninsula where the sediments consist of open clay patches with a labyrinth of crevices $R$. harrisii shares these crevices with $P$. hirtellus, where they coexist side by side.

The collections of the Zoological Institute of the Russian Academy of Sciences in St. Petersburg indicate an occurrence of Brachynotus sexdentatus (Risso, 1827 ) in the Bay prior to the introduction of $R$. harrisii (catalogue number 38281). This species was not found during our 5-years studies in the Taman Bay in different seasons.

Transect observations and censuses in shallow coastal flats of the Taman Bay

\section{Crabs' habitat and habits}

Specimens of Rhithropanopeus harrisii in the shallow water near village Sennoi are usually lightly colored (sandy yellow) and are often found in burrows as well as in the open. We have never observed this crab in the process of digging a burrow, thus we cannot assume they are made by the crab. Male or some large females of $R$. harrisii are often found in large burrows with 2 or multiple entrances (Figs 2B, C and 3). This is very similar to the burrows occupied by gobies. Rarely, they have been observed sharing a burrow with multiple entrances with the fish, but never with each other.

Many females lead a cryptic life and in 2011 they were often found in small pockets underneath macro- phyte roots, with no apparent entrances. These pockets were only located by pocking through the roots with fingers. None of these pockets were found in subsequent years or in any other location. When staying in the open, most of large males were assuming a defense position with open claws raised towards the observer. Smaller crabs frequently flee to their nearby burrows or burry themselves in rare sandy patches, which could be spotted easily due to darker colored sand. Often crabs took no notice of the researcher and continued their feeding. During the observations the sampler hardly moved and took a long time to search the area.

Crab counts

After several trials in 2011 we have successfully completed 8 transect censuses: 3 at 6:30 in the morning $\left(1.5\right.$ crabs per $\left.\mathrm{m}^{2}\right), 2$ at noon $\left(1.37\right.$ crabs per $\left.\mathrm{m}^{2}\right)$ and 3 at $6: 30$ in the evening $\left(1.4\right.$ crabs per $\left.\mathrm{m}^{2}\right)$, on average 1.44 Harris mud crabs per $\mathrm{m}^{2}$.

Overall we have collected 1096 living crabs: 434 $(40 \%)$ in the morning, $264(24 \%)$ at noon and 398 $(36 \%)$ in the evening. More than half (about $60 \%$ of the total count) crabs have been found in burrows. Sex ratio was biased towards males $78 \%, 13 \%$ non-ovigerous females and $10 \%$ were ovigerous females. The breakdown of numbers and percentages of crabs found in July 2011 are summarized in Tables 2 and 3.

Table 3. Number of crabs found at different time of day on different standard transects in July 2011, in the Taman Bay. Таблица 3. Количество крабов обнаруженных в разное время суток на стандартных трансектах в июле 2011 г. в Таманском заливе.

\begin{tabular}{|l|c|c|c|c|}
\hline \multirow{2}{*}{$\begin{array}{c}\text { Time of the } \\
\text { day }\end{array}$} & \multicolumn{3}{|c|}{ Days } & \multirow{2}{*}{ Total } \\
\cline { 2 - 4 } & $\mathbf{1}$ & $\mathbf{2}$ & $\mathbf{3}$ & \\
\hline Morning & 136 & 187 & 111 & 434 \\
\hline Noon & 121 & 143 & & 264 \\
\hline Evening & 102 & 175 & 121 & 398 \\
\hline
\end{tabular}


Table 4. Number and percentage of male, non-ovigerous (non-ov.) and ovigerous (ov.) females, found at different time of day on standard transects in July 2011, in the Taman Bay (sum in a row equals to $100 \%$ ).

Таблица 4. Количество и доля (\%) самцов, самок без (non-ov.) и с икрой (ov.) на плеоподах, обнаруженных в разное время суток на стандартных трансектах в июле 2011 г., в Таманском заливе (сумма в строке 100\%).

\begin{tabular}{|l|c|c|c|c|c|c|c|}
\hline \multirow{2}{*}{} & \multirow{2}{*}{$\begin{array}{c}\text { Nof } \\
\text { samples }\end{array}$} & \multicolumn{2}{|c|}{ Males } & \multicolumn{2}{c|}{ Non-ov. females } & \multicolumn{2}{c|}{ Ov. females } \\
\cline { 3 - 8 } & $\mathbf{n}$ & $\mathbf{\%}$ & $\mathbf{n}$ & $\mathbf{\%}$ & $\mathbf{n}$ & $\%$ \\
\hline Morning & 3 & 327 & $75 \%$ & 61 & $14 \%$ & 46 & $11 \%$ \\
\hline Noon & 2 & 215 & $81 \%$ & 30 & $11 \%$ & 19 & $7 \%$ \\
\hline Evening & 3 & 308 & $77 \%$ & 47 & $12 \%$ & 43 & $11 \%$ \\
\hline Total n & 8 & 850 & - & 138 & - & 108 & - \\
\hline
\end{tabular}

One-tailed ANOVA test has been performed to compare sizes of crabs found at particular transect censuses. There was a significant difference $(\mathrm{df}=7, \mathrm{p}<2 \mathrm{e}-16)$, but a post Hoc Turkey test has revealed that there is only one transect which is an outlier. Crabs from this transect were measured in the lab using calipers whereas a ruler has been used to measure the $\mathrm{CW}$ of crabs from the 7 transects in the field. Due to this, the measurement error is not comparable. Without this sample all transect samples revealed no significant differences in $\mathrm{CW}$ of collected crabs $(\mathrm{df}=6, \mathrm{p}=0.156)$; this indicated a comparability of sampling effort between particular censuses. Thus, for further analysis using size of specimens, the sample measure by the caliper was excluded from the data (resulting number of observations 909).

In July 2013 no females have been found in the vicinity of Sennoi and Volna Revolyutsii villages and the Rubanov peninsula. Near the shore, close to Taman town, no females have been observed either, but further away, at approximately $4.5 \mathrm{~m}$ depth, several females have been collected. Due to this finding 3 more $100 \mathrm{~m}$ transects (at 1.5, 2 and $3 \mathrm{~m}$ depths) using SCUBA instead of snorkeling have been made. These transects were parallel to the shore where the standard perpendicular transects have been sampled near Sennoi village. Crabs were found only at 1.5 and $2 \mathrm{~m}$.
Once again, no females have been found at these depths. Overall 5 standard transects yielded 34 crabs, on average 0,068 crabs per $\mathrm{m}^{2}$. This is a much lower figure when compared to the 2011 data.

Similarly to July 2013, in June 2014 all crabs found near Sennoi were males except for one large female (CW $15.3 \mathrm{~mm}$ ). During sampling period the weather was stormy with high waves, which destabilized bottom sediments in shallow waters. Only 4 samples have been successfully obtained which yielded 21 crabs $\left(0.0525\right.$ crabs per $\left.\mathrm{m}^{2}\right)$. Thus summer abundance of mud crabs in coastal shallows near Sennoi decreased by two orders of magnitudes between the years 2011 and 2013-2014 (Table 4).

Hiding pattern of crabs with regard to sex, size and time of day

The most abundant samples of 2011 make it possible to analyze the crabs' pattern of hiding in burrows. The fraction of crabs found in and out of burrows varied among transects, the time of the day and between the males and females but the proportion of crabs hiding in burrows and other types of shelter i.e. pockets underneath macrophyte roots (see above) was always significant, 41 to $78 \%, 58.4 \pm 6.08 \%$ in average (Tables 5, 6).

To reveal the differences in size of crabs found in and out of burrows and other shelters at different time

Table 5. Number and percentage of male, non-ovigerous (Non-ov.) and ovigerous (Ov.) female of Rhithropanopeus harrisii found in (In) and out (Out) of burrows at different time of day on standard transects in July 2011, in the Taman Bay (sum in a column equals to $100 \%$ ).

Таблица 5. Количество и доля (\%) самцов, самок без (Non-ov.) и с икрой на плеоподах (Ov.) в пробах Rhithropanopeus harrisii, собранных в норках (In) и вне норок (Out) в разное время суток на стандартных трансектах в июле 2011 г., в Таманском заливе (сумма по столбцам 100\%).

\begin{tabular}{|l|c|c|c|c|c|c|c|c|c|c|}
\hline \multicolumn{2}{|c|}{} & \multicolumn{4}{|c|}{ Males } & \multicolumn{3}{c|}{ Non-ov. females } & \multicolumn{3}{c|}{ Ov. females } \\
\cline { 3 - 13 }$y$ & Mor. & Noon & Even. & Mor. & Noon & Even. & Morn. & Noon & Even. \\
\hline \multirow{2}{*}{$\boldsymbol{N}$} & 327 & 215 & 308 & 61 & 30 & 47 & 46 & 19 & 43 \\
\hline \multirow{3}{*}{ In } & $\mathbf{n}$ & 163 & 149 & 205 & 23 & 7 & 26 & 34 & 16 & 35 \\
\cline { 2 - 13 } & $\mathbf{\%}$ & $50 \%$ & $69 \%$ & $67 \%$ & $38 \%$ & $23 \%$ & $55 \%$ & $74 \%$ & $84 \%$ & $81 \%$ \\
\hline \multirow{3}{*}{ Out } & $\mathbf{n}$ & 164 & 66 & 103 & 38 & 23 & 21 & 12 & 3 & 8 \\
\cline { 2 - 13 } & $\mathbf{\%}$ & $50 \%$ & $31 \%$ & $33 \%$ & $62 \%$ & $77 \%$ & $45 \%$ & $26 \%$ & $16 \%$ & $19 \%$ \\
\hline
\end{tabular}

Mor. - Morning, Even. - Evening. $N$ - total number of crabs in particular group.

Mor . - утро, Even. - вечер, Ov. - самки с икрой. $N$ - общее количество крабов в определенной группе. 
A

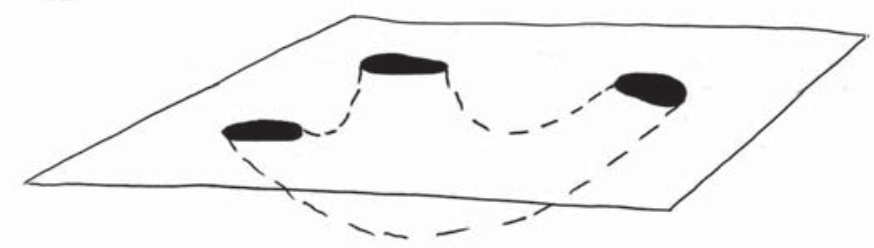

B

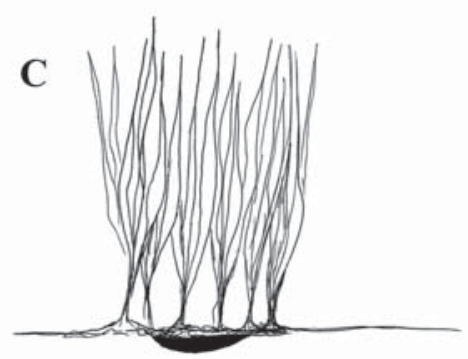

Fig. 3. Schemes of burrows where Rhithropanopeus harrisii can be found in the Taman Bay, Sea of Azov. Drawing by A.K. Zalota based on personal observations: A — burrow with multiple entrances, B — burrow with two entrances, C - burrow under roots; in this type of shelter most of females have been found in 2011.

Рис. 3. Схемы типов норок и других убежищ, в которых был обнаружен Rhithropanopeus harrisii в Таманском заливе. Рисунок А.К. Залота на основе личных наблюдений: А - норка с несколькими входами, В - норка с двумя входами, С - норка в корневищах макрофитов; в убежищах такого типа обнаружено большинство самок в 2011 г.

of day we have performed a two way ANOVA test (factor A - in vs out of burrows, factor B - samples). The results are summarized in Table 7 and Figs 4 and 5.

The sizes of crabs do not differ significantly in most cases, except for the non-ovigerous females in the morning. From the box plot (Fig. 5) it is possible to conclude that in the morning smaller females are hiding in burrows whereas larger are out and are possibly foraging. There are no statistically meaningful results for ovigerous females since no specimens have been found out of burrows and only 3 specimens were found hiding in the morning. Similar circumstances were observed at noon, thus the ANOVA results for ovigerous females at noon should be treated with caution.

One way ANOVA test has been used to analyze the differences in sizes of crabs collected between morning, noon and evening for each sex in and out of burrows. Similarly due to low sample size of ovigerous females found out of burrows no analysis has been done. Only ovigerous females in burrows have revealed significant difference of $\mathrm{CW}$ at different time of day $(\mathrm{p}=0.011)$, although based on the box plot (Fig. 5) we would expect to find such differences in all females. Post hoc analysis has revealed significant difference between the morning and the evening samples $(\mathrm{p}=0.0076)$.

Mixing model analysis has indicated that the male population in burrows comprises of 5 size groups, while only two most numerous groups (corresponding to groups 3 and 4) are present in the males collected out of burrows (Table 8; Figs 6A, B). The smallest groups with mean $\mathrm{CW} 7.6 \mathrm{~mm}$ and $9.6 \mathrm{~mm}$ and the largest group (mean CW $18.6 \mathrm{~mm}$ ) have not been recognized in males out of burrows (Table 8) which were however 1.56 times less numerous (Table 7). Although the number of non-ovigerous females in burrows was less than the number out of burrows, three groups have been recognized in this sample and only most numerous group 2 was present in the non-ovigerous females collected out of shelters (Table 8; Figs 6C, D). A very similar situation with the exception of the largest group absence was found in the ovigerous females (Table 8; Figs 6E, F).

Overall from Tables 5 to 8 and Figs. $4-6$ it is clear that the majority of males hide during the day (except in the morning similar numbers have been observed in and out of burrows). There are no major differences in sizes except the smallest males were more common in burrows. Non-ovigerous females preferred to be out during the day and became hidden towards the evening. There is a significant difference in size of females in the morning, where larger females were out of shelters and smaller ones were hiding in the burrows. Ovigerous females generally had cryptic habit during day light and few of them were found outside during our study.

\section{Aspects of size composition}

Quantitative sampling in shallow coastal flats in Taman Bay

For the largest sample collected near Sennoi in 2011 the Mixture Model Analysis has shown three size groups 
Morning $M$ in vs out

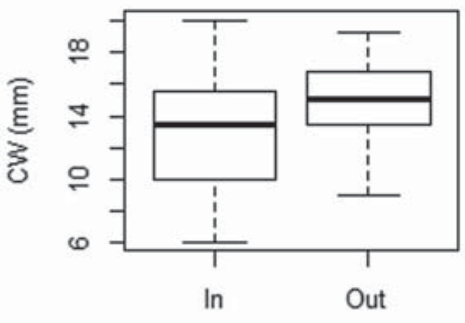

in vs out of burrows

Morning $F$ in vs out

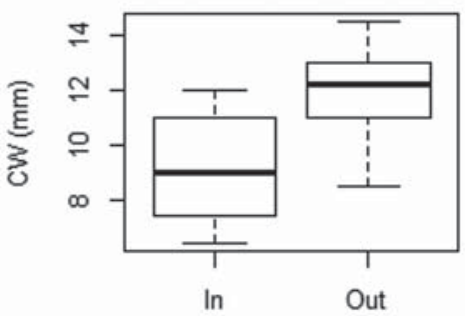

in vs out of burrows

Morning Fov in vs out

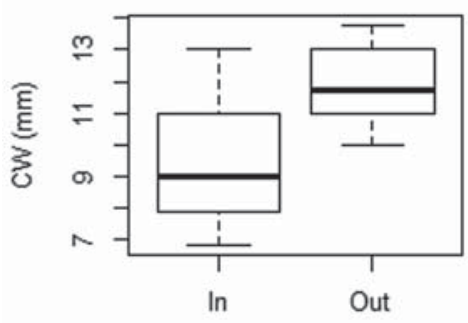

in vs out of burrows
Noon $M$ in vs out

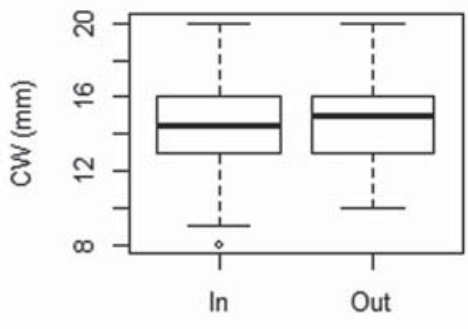

in vs out of burrows

Noon $F$ in vs out

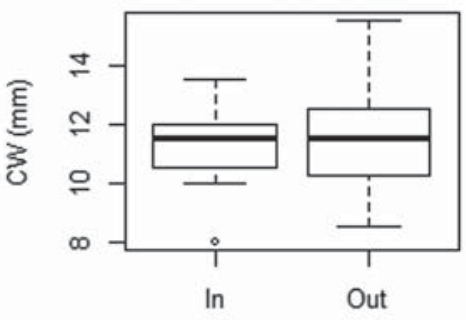

in vs out of burrows

Noon Fov in vs out

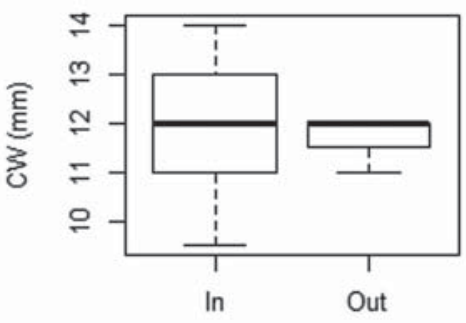

in vs out of burrows
Evening $M$ in vs out

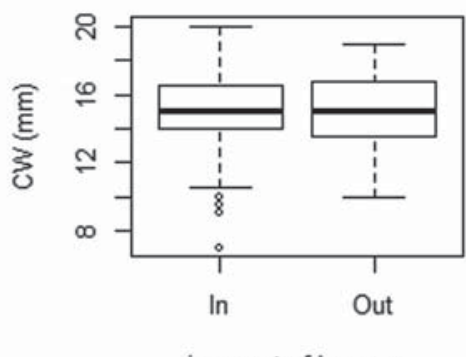

in vs out of burrows

Evening $F$ in vs out

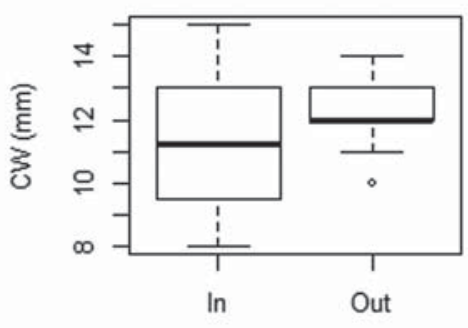

in vs out of burrows

Evening Fov in vs out

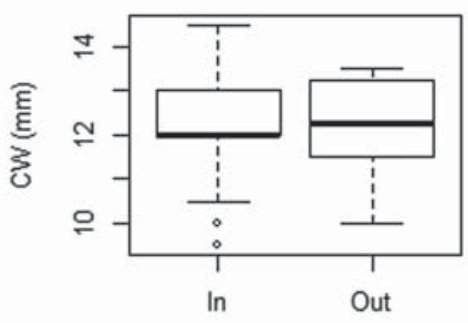

in vs out of burrows

Fig. 4. Box plot graphs of sizes of crabs found in or out of burrows grouped by sex and time of day, collected on standard transects in July 2011, in the Taman Bay.

Рис. 4. Диаграммы размаха размеров крабов, найденных в и вне норок, (разделенных по полу и времени суток; сбор на стандартных трансектах в июле 2011 г. в Таманском заливе.

of males with mean CW 12.4, 15.6 and 18.5 respectively, with the largest group constituting a small fraction of the sample (Table 9; Fig. 7A). Two additional small size groups were also identified in the subsample collected from burrows (Table 8; Fig. 6A, B). Females on the other hand had only two size groups (mean CW 9.2 and 12.1, where the second group in females corresponded to the group with mean CW $12.4 \mathrm{~mm}$ in males and the first group corresponded to the additional small group that was absent in the total male sample but present in the subsample collected from burrows).

Both ovigerous and non ovigerous female populations have been shown to comprise of the same two groups with characteristics similar to the overall female sample, the smaller group was proportionally less represented (Table 9; Figs 7B-D).

In July 2013 the sample was much smaller compared to 2011 and contained only males. For Mixture Model Analysis we used crabs that have been collected at the 5 standard and 2 depth transects. This analysis has produced 2 size groups with mean $\mathrm{CW}$ of 11.8 and $18.7 \mathrm{~mm}$ with a clear domination of a larger group (Fig. 8B). These two groups corresponded respectively to the smallest and the largest group of males in 2011 while anything similar to the intermediate group of 2011 was not detected. 
Males In crabs' CW vs time

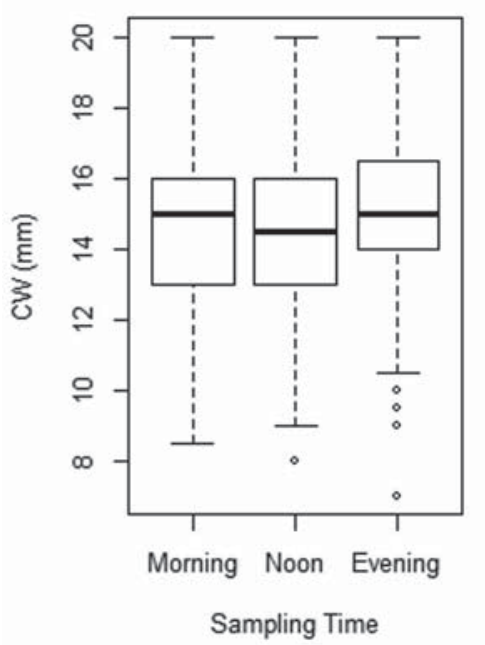

Males Out crabs' CW vs time

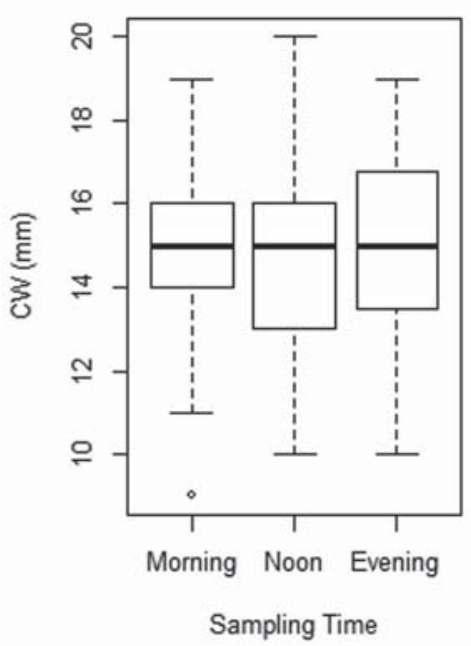

Female In crabs' CW vs time

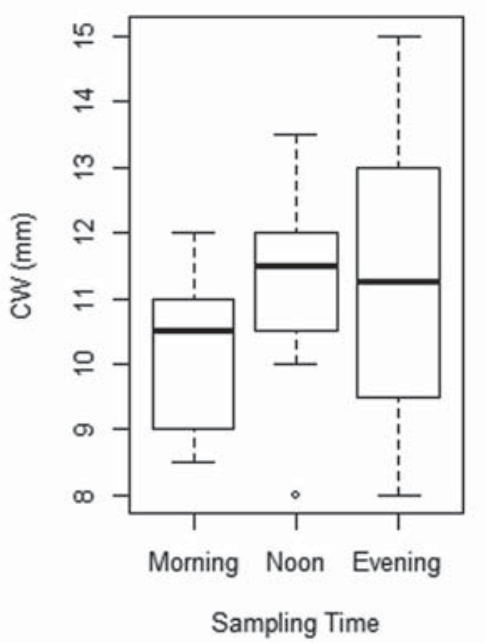

Female Out crabs' CW vs time

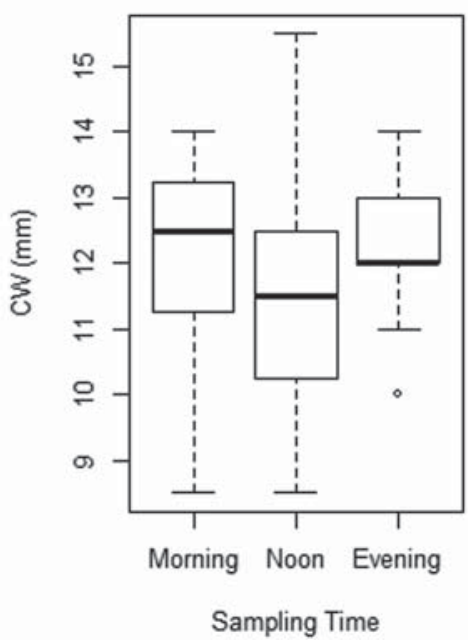

Fov In crabs' CW vs time

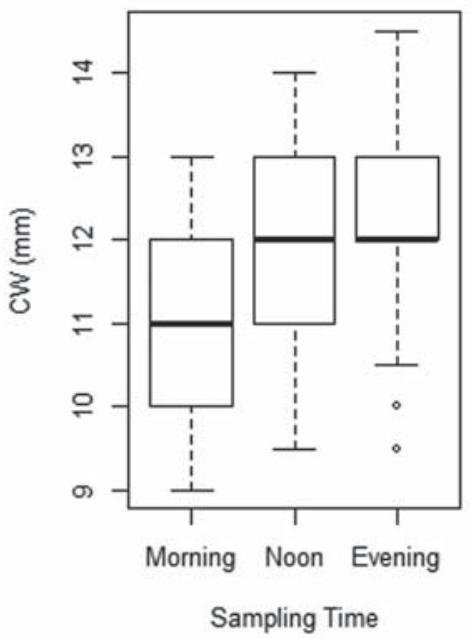

Fov Out crabs' CW vs time

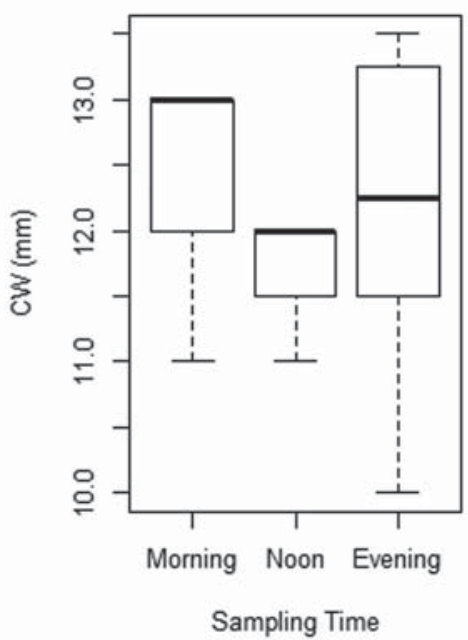

Fig. 5. Box plot graphs of CW sizes of crabs collected at different time of day grouped by sex and in or out of burrows, on standard transects in July 2011, in the Taman Bay.

Рис. 5. Диаграммы размаха размеров крабов, найденных в разное время суток (разделенных по полу и нахождению в или вне нор); сбор на стандартных трансектах в июле 2011 г. в Таманском заливе.

Similarly to July 2013 in June 2014, crabs were scanty and the sample was even smaller than in the previous year. The analysis has shown three size groups with mean CW 16.1, 19.9 and $23.0 \mathrm{~mm}$ respectively (Fig. 8C). These sizes are generally larger than respective sizes of the three groups in 2011 but the smallest group may be compared to the intermediate group of 2011, and the next to the largest group of 2011. The smallest group was strongly dominating; the other two consisted of few large crabs.

Characteristically sampling in shallow coastal flats near Sennoi revealed few small crabs and can characterize only two or three adult size groups which have been persistently present in the population between 2011 and 2014.

Smallest size group in the Taman Bay

Owing to occasional collection of small juveniles by bottom samplers in the benthic survey in July 2008 (see above) we can characterize the smallest size groups presumably right after settlement. This group was well separated from few specimens that apparently belonged to an older and larger group which was also present in the samples. Their mean $\mathrm{CW}$ was 3.6 (Fig. 8A). Three juvenile crabs with CW 2.4-3.2 mm have been collected from Zostera marina at depth 3$4 \mathrm{~m}$ using SCUBA diving in July 2011. We designate 

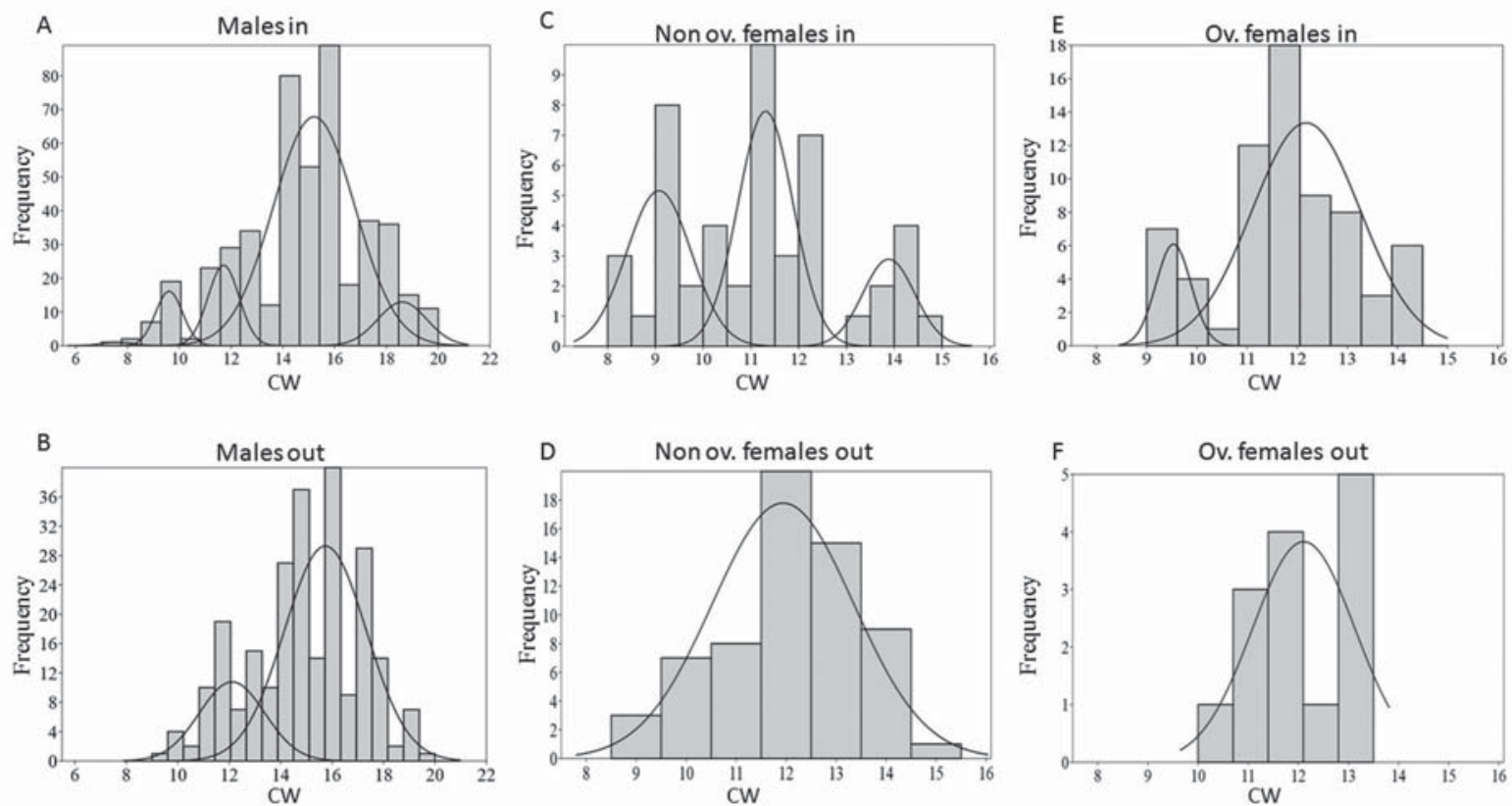

Fig. 6. Results of the mixing distribution analysis of size (CW, mm) composition of Rhithropanopeus harrisii collected in and out of burrows near Sennoi (Taman Bay) in July 2011. (see Table 8 for details).

Рис. 6. Результаты разделения смешанного распределения размеров (CW, мм) на нормально распределенные группы для Rhithropanopeus harrisii, собранных в и вне нор у пос. Сенной (Таманский залив) в июле 2011 г. (детали см. Табл. 8).

therefore juvenile crabs with $\mathrm{CW} 2-5 \mathrm{~mm}$ in summer to group 0.

Estuarine population in river Vulan in June 2013

Male size population structure analysis has resulted in 3 groups, with mean $\mathrm{CW}$ sizes of 8.1, 14.7 and 19.4 mm. (Table 10; Fig. 9A). The total female sample in the river has shown 3 groups (mean $\mathrm{CW}$ 8.8, 13.3 and $15.7 \mathrm{~mm}$ ) while females with and without eggs on pleopods taken separately comprised of only two groups (Table 10; Figs 9B-D). Groups of smaller size always outnumbered larger crabs.

Neither these data nor the size composition of small crabs in the benthic survey of 2008 can be directly compared to the Sennoi transect data because of different methods of collection. However, it appears that a group with average $\mathrm{CW}$ around $8-9 \mathrm{~mm}$ detected in widely dispersed samples in June-July likely represents the age group which is one year older than 0 group. At least part of females can mature and reproduce at the age of around one year (Figs 7D, 9D). The age of larger size groups must be greater but can't be estimated with certainty while the largest males $(\mathrm{CW}>$ $18 \mathrm{~mm}$ ) may have the age of more than 2 years.

\section{Dead crabs occurrence}

Dead crabs occurrence observed in July 2011 near Sennoi was of particular interest since it indicated significant mortality in the population in a restricted time. Out of 8 transects, 7 accounted for found dead crabs. Overall 42 dead crabs have been found out of burrows (mean CW size 16.33): 35 males $(83 \%), 5$ (12\%) non- ovigerous females, and $2(5 \%)$ ovigerous females. This proportion was not much different from the one found in live population.

Crabs were largely intact and not yet in process of decomposition that indicated their relatively recent death (not longer than a day earlier). Mean $\mathrm{CW}$ of dead males was shifted towards the largest size group in the male part of population, while female sizes corresponded to the largest size group of the female part of population (Figs 10A, B). Overall the size distribution of dead crabs was strongly asymmetric with mostly large crabs dying. Thus predominately large groups were affected by mortality. We speculate that this could be due to natural ageing process probably associated with the impact of unknown pathogens.

The populations densities in the following years have been much smaller and no dead crabs have been found. This once again suggests that the dead specimens found in 2011 could be a result of natural mortality which was detectable only at high general abundance of the population.

\section{Discussion}

Distribution of Harris mud crab in the Black and Azov seas

Vector of introduction of $R$. harrisii to the Black and Azov seas is not known with certainty. It was supposed that it came to the area with ship fouling [Makarov, 1939; Reznichenko, 1967]. Although, this species was recorded in the north-western Black sea 
Table 6. Number of Harris mud crabs found in and out of burrows on different standard transects at different time of day in July 2011, in the Taman Bay (100\% by day and transect In + Out).

Таблица 6. Количество крабов Харриса, обнаруженных в норках (In) и вне норок (Out), в разное время суток на стандартных трансектах в июле 2011 г., в Таманском заливе (100\% горизонтально по дням и трансектам в + вне).

\begin{tabular}{|l|c|c|c|c|c|c|}
\hline Counts & \multicolumn{2}{|c|}{ Morning } & \multicolumn{2}{c|}{ Noon } & \multicolumn{2}{c|}{ Evening } \\
\hline Transect & In & Out & In & Out & In & Out \\
\hline $\mathbf{1}$ & $101(74 \%)$ & $35(26 \%)$ & $94(78 \%)$ & $27(22 \%)$ & $73(72 \%)$ & $29(28 \%)$ \\
\hline 2 & $74(40 \%)$ & $113(60 \%)$ & $78(55 \%)$ & $65(45 \%)$ & $134(77 \%)$ & $41(23 \%)$ \\
\hline 3 & $4(41 \%)$ & $66(59 \%)$ & & & $59(49 \%)$ & $62(51 \%)$ \\
\hline
\end{tabular}

more than a decade earlier than in the Northern Sea of Azov (1937 vs. 1949), we could not be sure that Harris mud crab had initially invaded the north-western Black Sea and only then entered the Sea of Azov. Both areas have large merchant harbors such as Odessa, Kherson and Nikolaev (the nearest port to the first recorded mud crab locality in the area) in the first area, and Mariupol, Taganrog and Rostov in the Taganrog Bay of the Sea of Azov. Introduction via shipping could also have happen at about the same time (i.e. in the 1930s) in both areas, but the species was by chance first found at the advent of the World War II in the Dnieper-Bug liman and the war made research in the Sea of Azov impossible for several subsequent years.

The northwestern Black Sea (from the Danube delta to the isthmus of the Crimean Peninsula), and the Sea of Azov are similar in regard to the Harris mud crab distribution pattern. There, this species occurs along the open continental shore, in offshore banks, in limans, lagoons and estuaries and ports [MordukhaiBoltovskoy, 1952; Reznichenko, 1967; Makarov, 2004; Vinogradov et al., 2012]. In the Sea of Azov this species occurs in all habitats with the exception of oxygen depleted mud habitats in the deepest (10 $\mathrm{m}$ and deeper) area [Makarevich et al., 2000; Nabozhenko et al., 2010]. In some areas, i.e. the entrance to the Taganrog Bay, $R$. harrisii has been even recognized as a dominant species in the community according to the data of a small grab survey [Makarevich et al., 2000; Sergeeva, Burkatsky, 2002].

In the Taman Bay our observations indicate similar pattern of Harris mud distribution throughout the bay, although the occurrence of crabs in its extremely shallow north-western part [lacking sea grass vegetation; Spiridonov et al., 2016] is not yet confirmed.

The first finding of the species in the northern part of the Kerch strait dates to 1955 [in an unpublished master thesis by Nesis, 1956]. By 1989 R. harrisii was a common species in the communities dominated by Mytilus galloprovincialis and Mya arenaria in the northern and central but not southern parts of the strait [Ivanov, Sinegub, 2008].

Beside our survey, several other detailed surveys of Crimean inlets failed to find this species on the Black Sea coast of this peninsula [Revkov et al., 2007; Alyomov, 2012] even though it was earlier reported from the inner part of Sevastopol Bay [Shalovenkov, 2005].
It appears that, along most of the Crimean and Caucasian coast of the Black Sea $R$. harrisii occurs patchily. These patches are associated either with river estuaries (Vulan, Shap'sukho) or lagoons (such as Bugas Liman), which have restricted water exchange with the sea. Larvae of $R$. harrisii were also reported from the harbors of Anapa, Novorossiysk and Tuapse [Selifonova, 2012]. The species has not been reported from Turkey's coast of the Black Sea [GönlügürDemirci, 2006; Balkis et al., 2012]. No recent literature sources on the decapods distribution are available for Georgia's coast.

Even with significant knowledge gaps the distribution of Harris mud crab in the Black and Azov seas appears to be highly uneven. The rarity of the species along the Crimean coasts resembles its known occurrence pattern in the Mediterranean where $R$. harrisii is found in few lagoonal or estuarine habitats.

Table 7. Two way ANOVA p results (factor "place" - in vs out of burrows, factor sample - samples, place : sample - interaction term) of sizes of Harris mud crabs found on standard transects in the Taman Bay in July 2011.

Таблица 7. Результаты двухфакторного дисперсионного анализа (1-й фактор "place” — в или вне норки, 2-й фактор "sample" - номер пробы, place:sample взаимодействие факторов) размеров крабов Харриса, собранных на стандартных трансектах в Таманском заливе в июле 2011 г.

\begin{tabular}{|c|l|c|c|c|}
\hline Sex/group & \multicolumn{1}{|c|}{ Factor } & Morning & Noon & Evening \\
\hline \multirow{4}{*}{ Males } & place & 0.0797 & 0.92 & 0.784 \\
\cline { 2 - 5 } & sample & 0.0586 & 0.884 & 0.271 \\
\cline { 2 - 5 } & place:sample & 0.1142 & 0.63 & 0.49 \\
\hline \multirow{2}{*}{$\begin{array}{c}\text { Non- } \\
\text { ovigerous } \\
\text { females }\end{array}$} & place & $\mathbf{0 . 0 0 0 1 7}$ & 0.551 & 0.0661 \\
\cline { 2 - 5 } & sample & 0.64443 & 0.537 & 0.4776 \\
\cline { 2 - 5 } & place:sample & $\mathbf{0 . 0 1 6 7 8}$ & 0.859 & 0.2082 \\
\hline \multirow{3}{*}{$\begin{array}{c}\text { Ovigerous } \\
\text { females }\end{array}$} & place & NA & 0.8 & 0.9556 \\
\cline { 2 - 5 } & sample & NA & 0.392 & 0.5585 \\
\cline { 2 - 5 } & place:sample & NA & 0.474 & 0.0953 \\
\hline
\end{tabular}

NA - Not applicable; * statistically significant; degrees of freedom is 1 in all cases except sample factor in the evening where $\mathrm{df}=2$.

NA - неприложимо; * статистически значимое влияние фактора; количество степеней свободы (df) во всех случаях равно 1 , кроме фактора sample в вечернее время суток, где $\mathrm{df}=2$. 

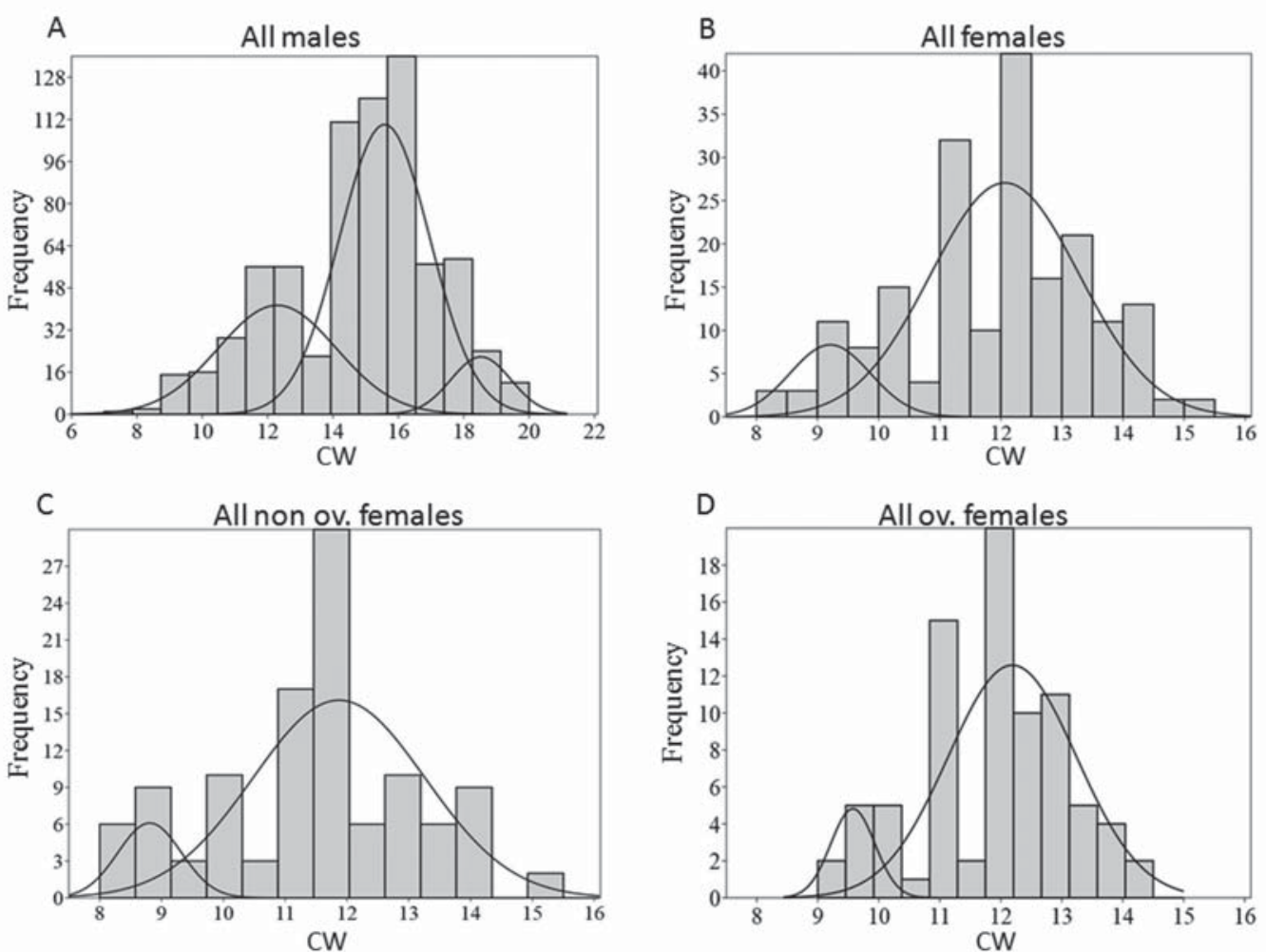

Fig. 7. Results of the mixing distribution analysis of size $(\mathrm{CW}, \mathrm{mm})$ composition of Rhithropanopeus harrisii collected near Sennoi (Taman Bay) in July 2011 (see Table 9 for details).

Рис. 7. Результаты разделения смешанного распределения размеров (CW, мм) на нормально распределенные группы для Rhithropanopeus harrisii, собранных у пос. Сенной (Таманский залив) в июле 2011 г. (детали см. Табл. 9).

The distribution pattern of the mud crab along the Black Sea coast of Romania and Bulgaria [Băcescu, 1952; Petrescu, Bălacşescu, 1995; Makarov, 2004; Skolka, Preda, 2010] and the Krasnodar area of Russia [present study] resembles the introduction area in the North Sea / Atlantic coast of Europe (Fig. 1A) and along the West coast of North America [Petersen, 2006], i.e. patchy association with estuaries and lagoons (or artificial lagoons such as harbors).

The occurrence of $R$. harrisii throughout entire seas (i.e. Sea of Azov with the Kerch Strait), their large parts [north-eastern Black Sea, northern Caspian Sea — see Reznichenko, 1967] or big bays (Taman Bay) is not common for this species in other areas of introduction. However this distribution pattern is found in its native range, along the eastern coast of North America; in particular in the Chesapeake Bay [Ryan, 1956] which is regarded as a large estuary.

Significant part of the Sea of Azov is influenced by runoff of Don and Kuban rivers; the north-western Black Sea receives fresh water from three other big European rivers: Danube, Dnieper, and Dniester. Only
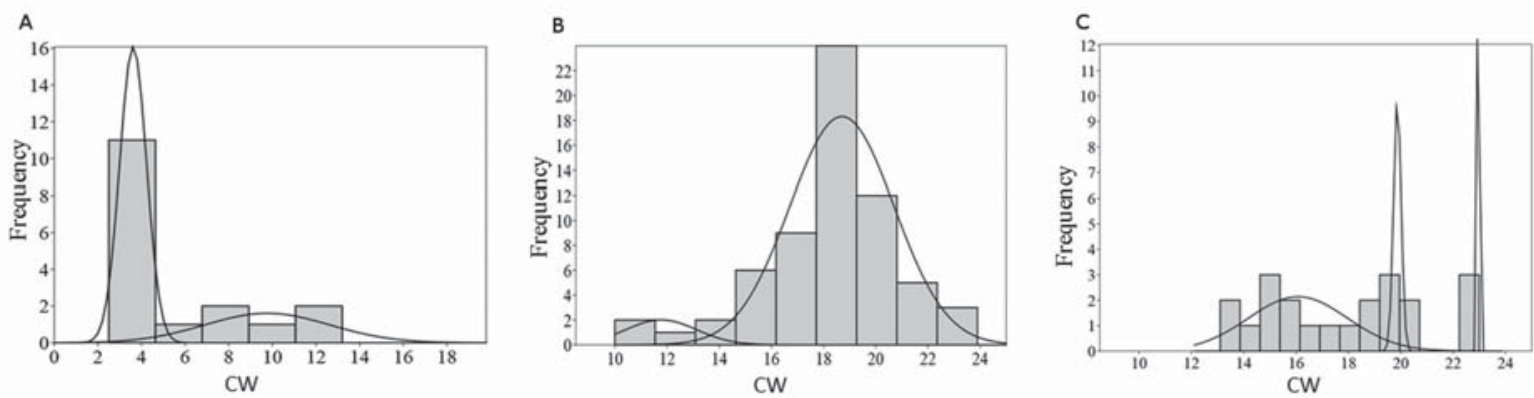

Fig. 8. Results of the mixing distribution analysis of size (CW, mm) composition of Rhithropanopeus harrisii collected during the benthic survey in the Taman Bay in 2008 (A) and near Sennoi town in 2013 (B) and 2014 (C).

Рис. 8. Результаты разделения смешанного распределения размеров (CW, мм) на нормально распределенные группы для Rhithropanopeus harrisii, собранных в ходе бентосной съемки в Таманском заливе в 2008 г. (А) и у пос. Сенной в 2013 (В) и 2014 (C) гг. 
Table 8. Characteristics of size groups revealed by the mixing distribution analysis of size composition of Rhithropanopeus harrisii collected in and out of burrows near Sennoi (Taman Bay) in July 2011. F — Non ovigerous females, Fov -

Ovigerous females, in - found in burrows, out - found out of burrows.

Таблица 8. Характеристики размерных групп крабов, выявленные с помощью разделения смешанного

распределения размеров Rhithrpanopeus harrisii, собранных около пос. Сенной (Таманский залив) в норках и вне норок в июле 2011г. F — самки без икры, Fov - самки с икрой, in - в норках, out - вне норок.

\begin{tabular}{|l|c|c|c|c|c|c|c|c|}
\hline \multicolumn{4}{|c|}{ Taman Bay 2011 } & \multicolumn{5}{c|}{ Group Means (CW, mm) } \\
\hline Sex/group & N of groups & $\begin{array}{l}\text { Log } \\
\text { likelihood }\end{array}$ & Akaike IC & $\mathbf{1}$ & $\mathbf{2}$ & $\mathbf{3}$ & $\mathbf{4}$ & $\mathbf{5}$ \\
\hline Males in & 5 & -642.8 & 1306 & $7.6 \pm 0.6$ & $9.6 \pm 0.5$ & $11.7 \pm 0.6$ & $15.2 \pm 1.6$ & $18.6 \pm 1$ \\
\hline Males out & 2 & -308.6 & 625.4 & & & $12.1 \pm 1.3$ & $15.7 \pm 1.6$ & \\
\hline F in & 3 & -44.4 & 102.8 & & $9.1 \pm 0.7$ & $11.3 \pm 0.6$ & $13.9 \pm 0.5$ & \\
\hline F out & 1 & -53.27 & 110.7 & & & $11.9 \pm 1.4$ & & \\
\hline Fov in & 2 & -50.57 & 109.8 & & $9.5 \pm 0.4$ & $12.2 \pm 1.1$ & & \\
\hline Fov out & 1 & -7.289 & 19.67 & & & $12.1 \pm 1$ & & \\
\hline
\end{tabular}

Table 9. Characteristics of size groups of Harris mud crab revealed by the mixing distribution analysis of size composition of Rhithropanopeus harrisii collected near Sennoi (Taman Bay) in July 2011 (total sample).

Таблица 9. Характеристики размерных групп крабов, выявленные с помощью разделения смешанного распределения размеров Rhithropanopeus harrisii, собранных около пос. Сенной (Таманский залив) в июле 2011 г. (объединенная выборка).

\begin{tabular}{|l|c|c|c|c|c|c|c|c|}
\hline \multicolumn{4}{|c|}{ Taman Bay 2011 } & \multicolumn{5}{c|}{ Group Means (CW, mm) } \\
\hline Sex/group & N of groups & Log likelihood & Akaike IC & $\mathbf{1}$ & $\mathbf{2}$ & $\mathbf{3}$ & $\mathbf{4}$ & $\mathbf{5}$ \\
\hline All males & 3 & -962 & 1936 & & & $12.4 \pm 1.8$ & $15.6 \pm 1.4$ & $18.5 \pm 0.9$ \\
\hline All females & 2 & -173.1 & 354.4 & & $9.2 \pm 0.7$ & $12.1 \pm 1.2$ & & \\
\hline All F & 2 & -107.9 & 224.3 & & $8.8 \pm 0.5$ & $11.9 \pm 1.4$ & & \\
\hline All Fov & 2 & -58.8 & 126.1 & & $9.6 \pm 0.4$ & $12.2 \pm 1.1$ & & \\
\hline
\end{tabular}

F — non-ovigerous females, Fov — ovigerous females.

F - самки без икры, Fov - самки с икрой.

Table 10. Characteristics of size groups revealed by the mixing distribution analysis of size composition of Rhithropanopeus harrisii collected from the river Vulan estuary (near village Arkhipo-Osipovka) in July 2013.

Таблица 10. Характеристики размерных групп, выявленные с помощью разделения смешанных распределений размеров Rhithrpanopeus harrisii, собранных в эстуарии реке Вулан (в районе поселка Архипо-Осиповка) в июле

2013 г.

\begin{tabular}{|l|c|c|c|c|c|c|c|}
\hline \multicolumn{4}{|c|}{ River Vulan 2013 } & \multicolumn{3}{c|}{ Group Means (CW, mm) } & \multirow{2}{*}{ Sample size } \\
\hline Sex/group & N of groups & Log lk.hood & Akaike IC & $\mathbf{1}$ & $\mathbf{2}$ & $\mathbf{3}$ & \\
\hline All Males & 3 & -61.9 & 138.9 & $8.1 \pm 1.9$ & $14.7 \pm 2.1$ & $19.4 \pm 0.4$ & 34 \\
\hline All Females & 3 & -46.7 & 109.3 & $8.8 \pm 2$ & $13.3 \pm 0.2$ & $15.7 \pm 1.9$ & 29 \\
\hline F & 2 & -20.2 & 52.9 & $6.9 \pm 0.9$ & $13.3 \pm 2.2$ & & 14 \\
\hline Fov & 2 & -18.6 & 49.25 & $9.7 \pm 0.4$ & $14 \pm 2.5$ & & 15 \\
\hline
\end{tabular}

F - Non-ovigerous females, Fov — ovigerous females.

$\mathrm{F}$ - самки без икры, Fov - самки с икрой. 
the Taman Bay lacks river discharge. Although neither the Sea of Azov, nor the north-western Black Sea can in strict sense be regarded as very large estuaries, and the Taman Bay is not an estuary, because it lacks river runoff and salinity gradient, the characteristic species in benthic communities in these waters are typical for the transitional (estuarine-lagoonal) European habitats [Vorobyev, 1949; Nesis, 1956; Golovkina, Nabozhenko, 2012; Spiridonov et al., 2016]. Both in the shallow north-western Black Sea and the Sea of Azov currents are generally wind-driven and change direction in response to meteorological situation [Zalogin, Kosarev, 1999]. Owing to this wind-driven circulation in semiclosed basins larvae of $R$. harrisii are maintained within a vast shallow area where salinity range does not exceed 18\%o (and usually ranges between 10 and $14 \%$ ) and depth and substrate conditions may favor their settlement. In the Taman Bay, post-metamorphic young crabs can (as we found in 2008: Fig. 1 C) settle in communities dominated by bivalves and seagrass that provide shelter; it is also similar for the Sea of Azov and the northern Kerch Strait where in particular cockle (Cerastoderma) and mussel (Mytilaster and Mytilus) beds are common [Vorobyev, 1949; Nesis, 1956; Ivanov, Sinegub, 2008]. Furthermore the Sea of Azov and the Taman Bay are practically devoid of other crabs species which can be active predators/competitors for mud crabs (only Pilumnus hirtellus occurs in the Taman Bay).

In coastal areas of the Black Sea along most part of the Crimean Peninsula and the Caucasian (north-eastern and eastern) coast the shelf is narrow, while currents usually have a dominant direction towards the north-west [Zalogin, Kosarev, 1999]. No larval retention mechanism [Forward, 2009] which would act with sufficient predictability, can be supposed for these nontidal areas, except for partial isolation of water bodies themselves (i.e. Bugas Liman) or existence of secondary circulations in slow flow estuaries with islands (i.e. Shap'sukho and Vulan rivers). The larvae that occur in the waters near the open Crimean and Caucasian coasts are subjected to the risk of being transported to areas with greater depth (over 20-30 m) which can be suboptimal for settling of metamophizing larvae.

In broad shallow area adjacent to the entrance of Kerch Strait neither depth nor salinity (up to 18-19\%o) are essentially different from the Taman Bay. However $R$. harrisii has not been found there (southern side of Tuzla spit, Zheleznyi Rog cape, off Blagoveschenskaya village and near Anapa; Fig. 1B) even though it occurs on the northern side of Tuzla spit and in the Bugas Liman which have direct connection to this part of the Black Sea (in the latter even at higher salinity than in the neighboring sea). Furthermore larvae of Harris mud crab have been found in the harbor of Anapa [Selifonova, 2012]. We speculate that either greater exposure of the coast to wave action and the dominance of sandy sediments in the nearshore zone from Anapa to the tip of Tuzla spit makes this habitat unsuitable for $R$. har- risii or /and the presence of other larger crab species (especially Liocarcinus vernalis and Eriphia verrucosa) increases predation risk for juvenile mud crabs. In fact, the Sea of Azov shores of Kerch Peninsula, where we have observed numerous mud crabs (Figs $1 \mathrm{~B}, 2 \mathrm{~A})$ are also open to high energy wave activity and the sediments are often disturbed, hence they are mostly sand or shell debris, similar to the Black Sea shore along the Bugas Liman. However, in the Sea of Azov the juveniles may settle and live elsewhere, where the conditions are more suitable, while in the Black Sea adjacent to the Kerch Strait such conditions may be absent. It is very likely that the presence of sheltered habitats for settled juveniles, such as sea grasses in Taman Bay, Mytilaster beds in the Sea of Azov or oyster reef in native habitats [Tolley et al., 2013] are of primary importance for maintaining mud crab populations in coastal areas.

In conclusion to the discussion of $R$. harrisii distribution in the Black Sea let us note that while estuarine and lagoonal populations along the Romanian and Bulgarian coasts could originate either owing to larval transport with south-westward currents from the northwestern Black Sea [Zalogin, Kosarev, 1999] or due to the shipping vector, i.e. vessels called to such ports as Constantza and Varna, the origin of Harris mud crab populations discovered by us in the estuaries of rivers Vulan and Shap'sukho is unclear. It is unlikely that the founders of these populations were brought by ships because there are no harbors in the vicinity of their localities. We suppose that the initial mud crab colonization of estuaries and limans along the North-Caucasian coast of the Black Sea was due to larval transport by currents. Currents there are generally directed northwestward towards the Kerch Strait [Zalogin, Kosarev, 1999] that makes advection of larvae from the Sea of Azov and the Taman Bay to the Caucasian coast of the Black Sea problematic. Alternative explanation would be an existence of yet not discovered populations of $R$. harrisii in the eastern Black Sea. It is likely that populations of Harris mud crabs exist in protected harbors of Tuapse and Novorossiysk, because the larvae of this species have been found there [Selifonova, 2012]. These areas along with the harbor of Poti in Georgia could host a not yet discovered stock of mud crabs which might have provided propagule pressure sufficient to establish smaller populations in the estuaries of the north-eastern coast of the Black Sea. To test our hypothesis one needs to survey harbors of the eastern Black Sea coast and obtain molecular genetic data to analyze relationships between different Black/Azov seas populations of $R$. harrisii.

\section{Habitats and hiding habit}

Although known by common name as "mud crab" $R$. harrisii lives in variety of habitats. In the Azov and Black seas they include practically all existing types of substrate from muddy sediments to sand with shell 

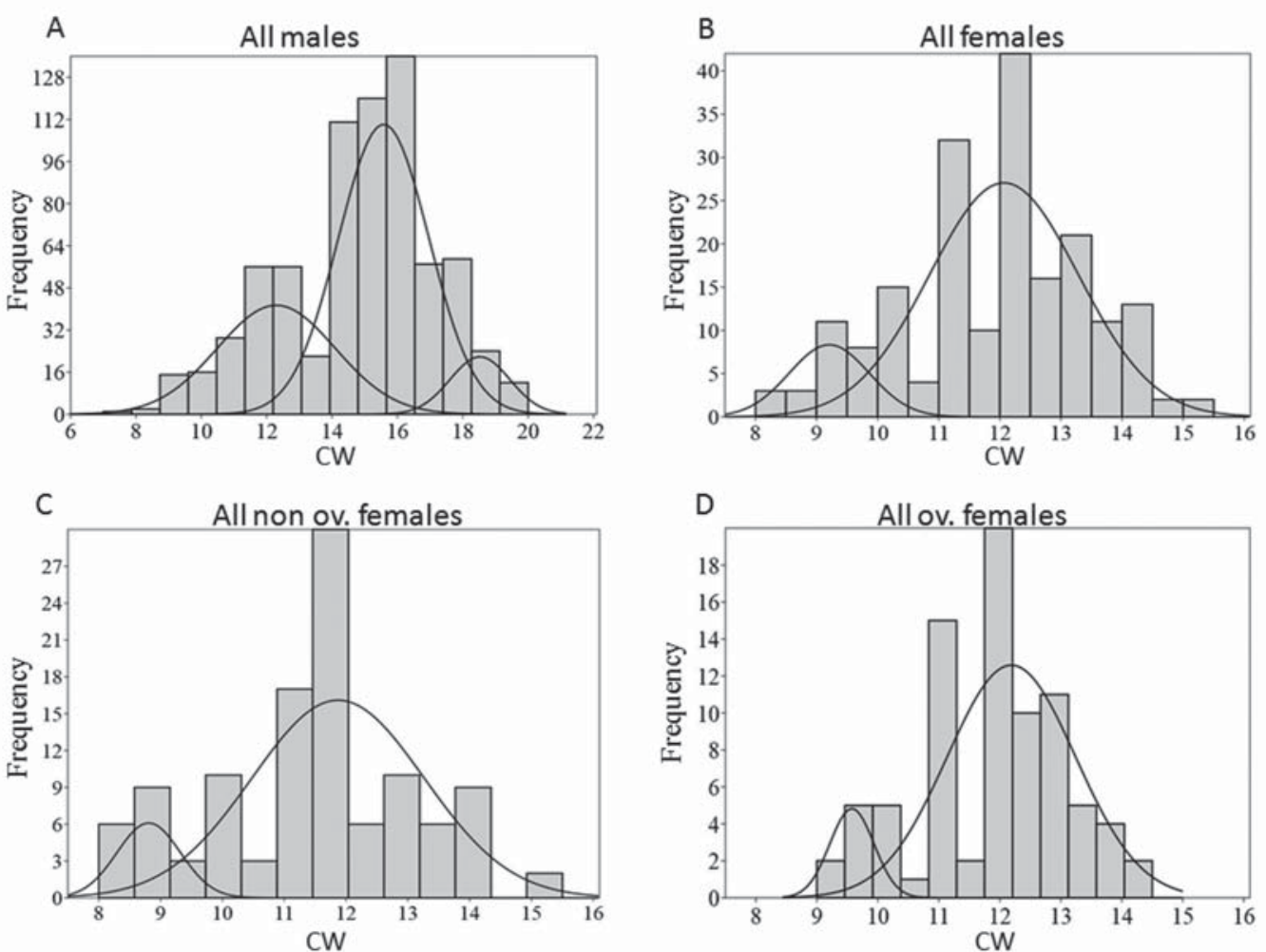

Fig. 9. Results of the mixing distribution analysis of size $(\mathrm{CW}, \mathrm{mm})$ composition of Rhithropanopeus harrisii collected from the river Vulan estuary in July 2013. (see Table 10)

Рис. 9. Результаты разделения смешанного распределения размеров (CW, мм) на нормально распределенные группы для Rhithropanopeus harrisii, собранных в эстуарии реки Вулан в июле 2013 г. (см. Табл. 10).

debris and stones (in particular on the Sea of Azov coast of Crimean Peninsula near Zolotoe village, see Fig. 2A). $R$. harrisii is spread throughout the Taman Bay and is found in all biotopes. At maximum depths (over 3 to $5 \mathrm{~m}$ ) crabs live on muddy sediments with shell. Females and juveniles were observed hiding under shells or in the folding of bacterial biofilms. In Zostera and Potamogeton overgrowths the crabs are hiding in burrows that are most probably dug out by gobies. Females are found in small inconspicuous pockets created by macrophyte roots with no definite entrances. At no time have we observed the crabs creating these burrows. The only burrowing activity that has been observed is a quick burrowing in the sand when attempting to hide from the observer. It seems that the crabs use available crevices and burrows created by other organisms or natural formations as in clay mazes or under stones and shells. In rivers, the crabs use roots of plants and stones that are available along the shore. It is unclear what happens on the bottom due to very low visibility, but the bottom of Vulan river is very soft and releases gas when disturbed. It is unlikely that there are any burrows in such sediments.

Our observations are in agreement with reports of other authors that studied Harris mud crab in both native and introduction areas. It has been reported that crabs live in oysters reefs (in native habitats), under stones, in various plant debris, in mud and sand with shell, and even among Fucus macroalgae on hard bottom [Ryan, 1956; Turoboyski, 1978; Petersen, 2006; Fowler et al., 2013]. In the experiment they preferred vegetated boulders compared to unvegetated boulders or sandy habitats [Nurkse et al., 2015]. This indicates a highly opportunistic habitat choice; however the presence of shelter appears to be a key factor [Petersen, 2006].

Our observations indicate that the use of shelter and hiding pattern significantly vary between different size, sex groups and localities. In the shallow sandy and shelly coastal beds with macrophyte overgrowth of the Taman Bay considerable part of population remains in the open while males and females showed different pattern of hiding (Tables 5, 6, 7 and Figs 4-6). Majority of males hide during the day and there is a tendency for smaller males to sit in burrows more often. Unfortunately, we were unable to conduct comparable night counts of crabs in the shelter and in the open. However, almost equal proportion of males in and out of burrows in the morning indicate greater occurrence of the crabs in the open in the dusk and/ or dark time which is probably associated with foraging. Contrary to this, non-ovigerous females preferred to be out during the day and hide towards the evening. In the morning, when significant part of males was still outside, larger females were out of shelters and smaller were hiding in the burrows. This indicates a separation of peaks of 
Table 11. Maximum and minimum sizes $(\mathrm{CW}, \mathrm{mm})$ of all Harris mud crabs crabs, males and females found on standard transects in the Taman bay at different years and in the river Vulan in 2013. Таблица 11. Максимальные и минимальные размеры (ширина карапакса, мм) всех крабов Харриса, самцов и самок, обнаруженных на стандартных трансектах Таманского залива в разные годы, а также в эстуарии реки Вулан в 2013

\begin{tabular}{|l|c|c|c|c|c|c|c|c|}
\hline Locality & Year & $\begin{array}{c}\text { N of } \\
\text { crabs }\end{array}$ & Max CW & $\begin{array}{c}\text { Min } \\
\text { CW }\end{array}$ & $\begin{array}{c}\text { Max CW } \\
\text { males }\end{array}$ & $\begin{array}{c}\text { Min CW } \\
\text { males }\end{array}$ & $\begin{array}{c}\text { Max CW } \\
\text { females }\end{array}$ & $\begin{array}{c}\text { Min CW } \\
\text { females }\end{array}$ \\
\hline \multirow{3}{*}{ Taman Bay } & Jul 2011 & 1096 & 20 & 7 & 20 & 7 & 15.5 & 8 \\
\cline { 2 - 9 } & Jul 2013 & 64 & 23.9 & 10 & & & & \\
\cline { 2 - 10 } & Jun 2014 & 21 & 23 & 13.1 & & & & \\
\hline River Vulan & July 2013 & 63 & 20 & 5 & 20 & 5 & 19.1 & 5 \\
\hline
\end{tabular}

Samples in the Taman Bay in 2013 and 2014 consisted mostly of males.

Пробы из Таманского залива в 2013 и 2014 гг. состояли преимущественно из самцов.

outside activity in crabs of different sex that probably leads to a decreased frequency of agonistic encounters between females and males which generally have larger size. Ovigerous females generally had cryptic habit during day light. Even though their out of burrows sample was too small for statistical analysis, one could speculate that while smaller ovigerous females were still hiding in the morning, the larger ones showed greater activity in open space. The mesocosm experiments with Harris mud crabs in the Baltic showed that they also have size-associated pattern of using different types of substrates and shelter and interspecific aggression and food availability play a role in crabs' pattern of using different habitats [Nurkse et al., 2015].

In contrast to $R$. harrisii in the Taman bay crabs in the Sea of Azov (near Zolotoe village) and in the river estuaries were practically not observed in the open. Crabs in the estuaries hide whenever there is slight movement. Such behavioral difference may be due to differences in predators' pressure in studied areas. Not much is known about predators of mud crabs in the Azov and Black seas except that they are consumed by several fish species [Reznichenko, 1967]. According to our visual observations potential predators in the shallow areas of the Taman Bay are mainly gobies usually not exceeding $30 \mathrm{~cm}$ in length and occur in moderate abundance (not more than 2-5 specimens per $10 \mathrm{~m}^{2}$ ). Cases of sharing burrows between gobies and crabs may indicate that at least for large adult crabs gobies are not a serious danger and combination of hiding (using existing burrows, macrophyte shelter and rapid burrowing in sand) and taking a defense position may be an effective strategy to tackle with potential predators.

Near Zolotoe village only stones provide shelter while sediments (shell debris and coarse sand) may be hard for rapid burrowing. Together with high abundance of large size gobies (Fig. 2A) this probably resulted in a totally adopted cryptic habit of crabs.

We can only speculate that the hiding behavior of Harris mud crabs in the north-eastern Black Sea estuaries is also related to the interaction with predators. According to communication of local people freshwater fishes are common in the estuaries thus possibly provide high predator pressure. Other potential preda- tors could be water birds. Not only the ability to use a variety of substrates, but also a flexible hiding behavior is part of opportunistic strategy of $R$. harrisii facilitating its survival and thriving in various areas of introduction.

\section{Size range of Harris mud crabs}

Size composition data of $R$. harrisii in literature came from using different methods of collecting, so it is only the size ranges that can be generally compared. In different localities of Poland's Baltic waters the minimum size $(\mathrm{CW})$ of males ranged between 2.9 and $5.6 \mathrm{~mm}$ and the maximum size - between 21.4 and 26.0; those of females ranged between 1.9-5.3 and 16.1-19.8 mm [Hegele-Drywa et al., 2014]. In the Bay of Finland, respective ranges for males and females were 2.2-22.0 and 2.1-20.2 [Fowler et al., 2013]. The size range of crabs in the Taman Bay and in the Vulan River estuary (Table 11) corresponds well with the data for the Baltic Sea populations. It was earlier observed [Fowler et al., 2013; Hegele-Drywa et al., 2014] that $R$. harrisii attains greater size in its Baltic introduction area than in its native distribution range, i.e. Chesapeake Bay, Louisiana where males larger than 18 $\mathrm{mm}$, and females larger than $16 \mathrm{~mm}$ have not been reported [Ryan, 1956; Williams, 1984; Fowler et al., 2013]. In our Taman Bay samples CW around $18 \mathrm{~mm}$ was repeatedly recorded as a mean size of the largest size group (Figs 6-8; Tables 8, 9). On the basis of our data and observations by Makarov [1939] we conclude that attaining larger size in introduction areas also stands true for the Black and Azov seas population of Harris crab. It follows a general pattern revealed for most studied marine invasive species, the majority of which become significantly larger in the introduced range compared to the native range with little evidence for any decrease in size following invasion [Grosholz, Ruiz, 2003]. Even though no mechanism explaining this increase has been demonstrated in details [Grosholz, Ruiz, 2003] our observations in the Taman Bay indirectly suggest that the decrease of predator pressure may be an important factor. This should be taken into account in further studies of mud crabs in the Black and Azov seas. 
A

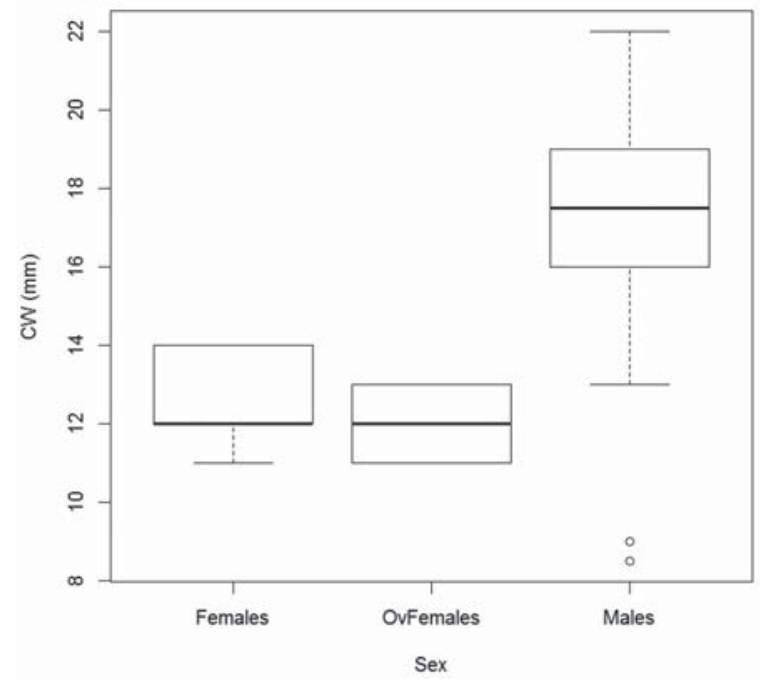

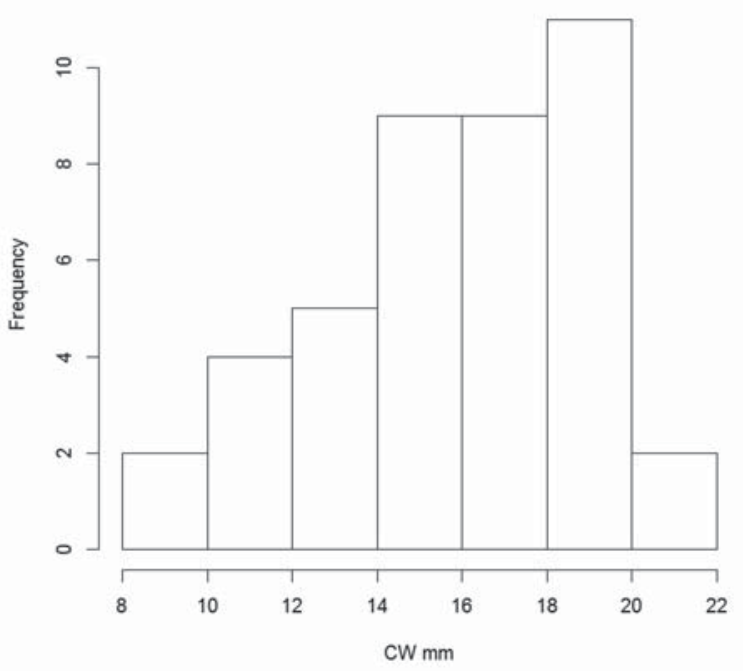
2011.

Fig. 10. Box plot of size versus sex (A) and size histogram (B) of dead crabs found on standard transects in the Taman Bay in July

Рис. 10. Диаграмма размаха размеров (А) и гистограмма (В) размерного ряда мертвых крабов (разделенных по полу), собранных на стандартных трансектах в июле 2011 г. в Таманском заливе.

Composition and dynamics of Harris mud crab in coastal shallow beds of the Taman Bay

The shallow coastal flats near Sennoi where we conducted transect censuses of $R$. harrisii in 2011, 2013 and 2014 appear to be generally favorable habitats for this species in summer. This is due to relatively low predators pressure, at least for larger crabs (see above) and a mosaic pattern of macrophyte dominated benthic communities providing a variety of prey items for Harris mud crabs which are generalist predators and scavengers [Zalota et al., 2013; Kolesnichenko, 2014]. The disadvantages for living in this zone include risks of storm disturbance, particularly in autumn and winter, and heating of the water in calm summer days which may cause hypoxia recorded from time to time in shallow area of the Taman Bay [Spiridonov et al., 2016].

Male to female ratio in our collections in the Taman Bay shallows was biased towards males $78 \%$; Table 4) in 2011 while in 2013 and 2014 samples consisted practically entirely of males. Broad surveys in Dead Vistula and the Gulf of Gdansk using dredges indicated only slight excess of males. i.e 54\% [Turoboyski, 1973] and 52\% [Hegele-Drywa et al., 2014] of adult population respectively. Similar fraction of males has been reported by Reznichenko [1967] for the Sea of Azov in general (although the method of collecting was not described in details). In the season-long crate collecting in the Gulf of Finland male to female ratio varied from 44 to $51 \%$ and did not show significant differences between locations and different years [Fowler et al., 2013]. On the other hand in the Taganrog Bay males comprised $82 \%$ (similar to our results) of samples [Reznichenko, 1967]. Another surprisingly similar figure (about $82 \%$ of males) was found by Kolesnichenko
[2014] who collected crabs by digging sediments near the watermark in the Russian part of the Vistula Bay in summer. Vorstman [1939] also reported several cases of strong (up 100\%) dominance of males in particular habitats in Netherlands.

One of the explanations for biased sex ratio in the coastal shallows of the Taman Bay is that females which maintain cryptic way of life were underestimated. In this case we would expect a much higher number of females found in the shelter (burrows) than out of the shelter. This was not however the case (Table 5), so the main source of underestimation could be that the females completely burrowed themselves in sediments. However if this was a common case we would observe at least certain amount of crabs sitting entirely in sand because the inspection of transects proceeded with slow speed and was carefully surveyed. Indeed some crabs burrowed themselves in sand when being disturbed but this was easily noticed. Therefore we believe that underestimation of females was not really high and our figures reflect a real situation in the shallows of the Taman Bay.

Our study revealed two or three adult size groups of Harris mud crab which have been persistently present in the coastal shallows of the Taman Bay between 2011 and 2014. Characteristically smaller size groups were deficient. This could again be due to the collection method but in 2011 small crabs of $5-6 \mathrm{~mm}(\mathrm{CW})$ were spotted and collected. We could also see and potentially count other small creatures such as hermit crabs, Idothea, and others. Thus even assuming underestimation of smaller size groups of crabs we conclude that shallow coastal areas in the Taman Bay in summer are populated by predominately males of larger size groups. Females may be also present as we discovered them in summer 2011, some of them being in process 
of carrying developing eggs on pleopods, and in April 2014 when mating was observed [unpublished observations of the first author]. However, one can easily suggest that release of larvae in the shallow banks poses high risks of negative effects of surge on larvae. Thus larvae hatching in this part of the bay could be an unsuccessful strategy and females most likely migrate to deeper areas prior to hatching. Consequently during the breeding season sex ratio of crabs inhabiting coastal shallows is biased towards males. Also coastal flats near Sennoi (depth $<1.5 \mathrm{~m}$ ) are unlikely to be populated by crabs in winter because of frequent storms and seasonal diminishing of macrophyte vegetation [observations by authors]. Therefore, it is likely that the population of $R$. harrisii in the Taman Bay has a complex spatial structure with different age groups, males and females occupying partly different habitats and performing seasonal migrations. Even though our sampling methods in the Taman Bay and in the river estuaries do not allow for full correct comparison of the data, simultaneous presence of juvenile crabs and adult females (including ovigerous) and males (Fig. 9) indicate that in the estuaries all these groups live more or less together. This is because the area populated by mud crabs is simply much too small for the establishment of a complex spatial structure. We can further speculate that spatial overlapping of different age groups and sexes in the estuaries result in frequent agonistic interactions between crabs and even cannibalistic predation of smaller and molting specimens so that extremely expressed hiding pattern of the estuarine crabs receive additional explanation.

Our four years transect censuses in the Taman Bay covered only part of population which temporarily occupies coastal shallow bank. The timing of occupation is also not known with certainty. Only with caution we can interpret tremendous changes in abundance between 2011 on one hand and 2013 and 2014 (by two orders of magnitude) on the other hand as an indication of pulsation of population abundance between years. When having frequently observed dead crabs in 2011 we probably witnessed ageing and dying off a highly abundant generation, which exceeded in strength generations of subsequent years.

Further development of methodology to study Harris mud crab populations

The method of direct observation and hand collection of Harris mud crab in situ used in present study clearly shows its strength and limitations. First of all it is probably optimal for rapid assessment and detection of the species in relatively clear water with various, including coarse substrates and abundant macrophyte growth. On the coasts of the Black and Azov seas it is logistically most feasible because everything that is required is a vehicle and snorkeling/ diving equipment. It also provides valuable information on habitats and especially microhabitats populated by crabs and pattern of using shelter that would be practically impossi- ble to obtain by any other means, including dredging [Turoboyski, 1973] and long term collecting in crates [Roche, Torchin, 2007]. Underwater transect censuses also provides quantitative estimates of abundance but only for particular habitats, i.e. shallow areas with mixed sediment bottom and appropriate visibility. However, besides visibility there are several problems in applying transect counting, in particular massive development of filamentous algae on the bottom that prevents effective search of crabs. In deeper areas if SCUBA is used additional technical problems arise from unavoidable disturbing of sediments that also worsen search condition. Using a less invasive and rapidly applicable to larger surveyed areas methods such as applying a calibrated bar for virtual construction of a sampling quadrate [Miljutin, 2005] can probably solve this problem.

To study composition and dynamics of such extensively distributed and spatially structured populations of $R$. harrisii as the population in the Taman Bay a combination of methods should be applied with direct censuses in shallow areas, dredging on soft bottom with sparse vegetation, and qualitative collecting in dense Zostera marina beds using SCUBA. For estuaries similar to Vulan river, as well as for harbors the most appropriate way to collect material comparable between sites and years is installation of crates. Populations of $R$. harrisii in other areas may require specific combinations of different sampling approaches.

\section{Conclusions}

The present study provided new data on the distribution of Rhithropanopeus harrisii in the eastern part of the Black Sea - Azov Basin and indicated its patchy distribution along the eastern coast of the Black Sea with newly discovered populations in two river estuaries (Vulan and Shap'sukho), and in the Bugas liman adjacent to the Black Sea. Furthermore we have shown a wide occurrence of the species in the Taman Bay located at the boundary between the Sea of Azov and the Black Sea and opening to the Kerch Strait. In the shallow area of the Black Sea adjacent to the Taman Bay and the Bugas Liman (where neither depth nor salinity are essentially different from the above areas) no indications of Harris mud crab's presence were found. We speculated that this may be due to limitation of optimal possibilities for settlement of young crabs and/ or the presence of abundant native crab species populations.

Harris mud crabs have been found in very distinct shallow water habitats spanning from exposed shores with sandy, shell and stones on the Crimean coast of the Sea of Azov to extensive Zostera spp. meadows in the Taman Bay and narrow bands of reed roots along the river estuaries. The only common characteristic of these habitats is their ability to provide shelter. Direct observations and censuses in the Taman Bay indicated that smaller crabs of both sexes and most of ovigerous females prefer to hide in burrows. Overall, a flexible hiding behavior is part of opportunistic strategy of $R$. harrisii facilitating its survival and thriving in various 
areas of introduction. Seemingly, there is a seasonal migration pattern of $R$. harrisii in the shallows of the Taman Bay and no such observations are apparent in the estuary habitats on the Black Sea coast.

Similarly to the Baltic, $R$. harrisii attains greater size in the Black Sea and the Sea of Azov than in the native distribution range. A complex size structure including two or three size groups of adult/ subadult crabs (except newly settled juveniles) is characteristic for both the Taman Bay and the estuarine populations. Thus, although, the distribution and migration patterns of different size groups differ, the general life cycle of the studied crab populations appears to be similar.

ACKNOWLEDGEMENTS. We would like to thank Ulyana Simakova for providing information and identification of the Taman Bay vegetation and support in the research organization, Sergey Anosov for his support and logistic organization of the Crimean peninsula and Krasnodar region surveys in 2013. The expedition along the Krasnodar region Black Sea shore and Sea of Azov lagoons has been conducted in collaboration with the Institute of Arid Zones, Southern Scientific Center of Russian Academy of Sciences in the year 2012. We would like to express our gratefulness to the head of this expedition Maxim Nabozhenko and the team for their great help and making it possible. We would also like to thank Sergey Olkhovsky, the leader of the underwater archeological division of the Phanagoria Archeological Expedition and his team for accommodation, catering and technical support. Our gratitude extends to Jonne Kotta, Lesya Garlitska and Andrei Azovsky who kindly reviewed the manuscript and provided valuable comments.

The field work was supported by the Russian Foundation for Basic Research (RFBR) Grant No. 13-04-01127 and the Presidium of Russian Academy of Sciences (Program 23).The analysis and preparation of the manuscript was funded by Russian Fund for Basic Research (RFBR Grant No. 13-04-01127) — AZ, VS; and by the main research direction of the Laboratory of Ecology of Coastal Bottom Communities of IO RAS - GK.

\section{References}

Akaike H. 1974. A new look at the statistical model identification // IEEE Transactions on Automatic Control. Vol.19. P.716-723.

Andreev N.I., Andreeva S.I. 1988. [Crab Rhithropanopeus harrisii (Decapoda, Xanthidae) in the Aral Sea] // Zoologicheskiy Zjurnal. Vol.67. No.1. P.135-136 [in Russian].

Alyomov S.V. 2012. Macrozoobenthos // V.N. Eremeev, A.R. Boltachev (Eds.). Biological diversity of the coastal zone of the Crimean Peninsula: problems, preservation and restoration pathways. Sevastopol: Institute of Biology of the Southern Seas, NAS of Ukraine. P.33-44.

Basescu M. 1952. Rhithropanopeus harrisii rtidentatus (Maitland) un crab american patruns si aclimatizat de curand in lagunele salcii ale razelmulni // Bul. St. Acad. R.P.R. Sect. St. Biol. Vol.4. No.3. P.571-578.

Bacevièius E., Gasiûnaitë Z.R. 2008. Two crab species-Chinese mitten crab (Eriocheir sinensis Edw.) and mud crab (Rhithropanopeus harrisii (Gould) ssp. tridentatus (Maitland)) in the Lithuanian coastal waters, Baltic Sea // Transitional Waters Bulletin.Vol.2. P.63-68.

Balkis H., Mülaim A., Perçin-Paçal F. 2012. Decapod crustacean fauna of the Black Sea coast of Istanbul // Crustaceana. Vol. 85. P.897-908.

Ben Souissi J., Zaouali J., Rezig M., Neimeddine Bradai M., Quignard J.P., Rudman B. 2004. Contribution à l'étude de quelques récentes migrations d'espèces exotiques dans les eaux Tunisiennes // Rapports de la Commission Internationale pour 1'Exploration Scientifique de la Mer Méditerranée. Vol.37. P.312.

Cuesta J.A., Garcýa-Raso J.E., Gonzalez-Gordillo J.I. 1991. Primera cita de Rhithropanopeus harrisii (Gould, 1841) (Crustacea, Decapoda, Brachyura, Xanthidae) en la Penýnsula Iberica // Boletýn del Instituto Espanol de Oceanografýa. Vol.7. P.149153.

Eno N.C., Clark R.A., Sanderson W.G. 1997. Non-native marine species in British waters: a review and directory. Peterborough: Joint Nature Conservation Committee. 152 p.

Forward R.B. 2009. Larval biology of the crab Rhithropanopeus harrisii (Gould): a synthesis // Biological Bulletin.Vol.216. P.243-256.

Fowler A.E., Forsström T., von Numers M., Vesakoski O. 2013. The North American mud crab Rhithropanopeus harrisii (Gould, 1841) in newly colonized Northern Baltic Sea: distribution and ecology // Aquatic Invasions. Vol.8. No.1. P.89-96.

Golovkina E.M., Nabozhenko M.V. 2012. [Present-day condition of benthic communities of Kerch Strait (Russian sector) and lagoons of the Taman Peninsula] // Vestnik Yuzhnogo Nauchnogo Tsentra RAN. Vol.8. No.2. P.53-61 [in Russian].

Gönlügür-Demirci G. 2006. Crustacea fauna of the Turkish Black Sea coasts: a check-list // Crustaceana. Vol.79. No.9. P.1129-1139.

Grosholz E.D., Ruiz G.M. 2003. Biological invasions drive size increases in marine and estuarine invertebrates // Ecology Letters. Vol.6. P.700-705.

Hammer Ø. 2013. PAST: PAleontological STudies Version 3.0: Reference Manuel. Natural History Museum. Olso. http://folk.uio.no/ ohammer/past/past3manual.pdf Accessed 1 October 2015

Hegele-Drywa J., Normant M., Szwarc B., Pod³uska A. 2014. Population structure, morphometry and individual condition of the non-native crab Rhithropanopeus harrisii (Gould, 1841), a recent coloniser of the Gulf of Gdañsk (southern Baltic Sea) // Oceanologia.Vol.56. No.4. P. 805-824.

Ivanov D.A., Sinegub I.A. 2008. [Transformation of biocoenoses of the Kerch Strait after the introduction of predatory gastropod Rapana thomasiana and bivalves Mya areanaria and Cunearca cornea] // Proceedings International Conference "Problems of ecology of the Azov - Black Sea Basin", 1012.10.2007. Kerch. P.45-51 [in Russian].

Karhilahti A. 2010. Taskurapu tarttui pyydykseen // Suomen luonto. Vol.4. P.12-13.

Kerckhof F. 2001. National report for Belgium, Anex 3: National reports, Working Group on Introductions and Transfers of Marine Organisms (WGITMO) report.

Kolesnichenko A. 2014. Feeding ecology of invader crab Rhithropanopeus harrisii (Gould 1841) in the Vistula Bay. Master thesis. Kaliningrad: Kaliningrad State Technical University. [in Russian].

Kolyuchkina G.A., Spiridonov V.A., Belyaev N.A. et al. 2008. Report on preliminary results of the expedition of the P.P. Shirshov Institute of Oceanology and WWF Russia to the Kerch Strait area for investigating consequences of the black oil spill after the accident with tanker "Volgoneft'-139" on 11 November 2007. Moscow: WWF Russia. http://www.wwf.ru/ resources/publ/book/304 Accessed on 1 October 2015.

Kolyuchkina G.A., Spiridonov V.A., Simakova U.V., Peresypkin V.I., Belyaev N.A., Khlebopashev P.V., Makarov A.V., Sapozhnikov F.V., Kozlovsky E.S., Shapovalova E.S. 2009. Studies of long term consequences of catastrophic black oil spill in the Kerch Strait // Oceanology.Vol.49. P.742-744.

Kolyuchkina G.A., Belyaev N.A., Spiridonov V.A., Simakova U.V. 2012. Long-term effects of Kerch strait residual oil-spill: hydrocarbon concentration in bottom sediments and biomarkers in Mytilus galloprovincialis (Lamarck, 1819) // Turkish Journal of Fisheries and Aquatic Sciences. Vol.12. P.461-469.

Kolyuchkina G.A., Spiridonov V.A., Basin A.B., Kozlovskii V.V., Simakova U.V. 2013. Long-term changes of Taman bay macrozoobenthic communities // The $4^{\text {th }}$ Bi-annual Black Sea Conference: 28-31 October 2013, Constanta, Romania Black Sea 
- Challenges towards good environmental status. Abstracts book. Constanta: Editura Boldas. P.82.

Kotta J., Ojaveer H. 2012. Rapid establishment of the alien crab Rhithropanopeus harrisii (Gould) in the Gulf of Riga // Estonian Journal of Ecology.Vol.61. No.4. P.293-298.

Maitland R.T. 1874. Naamlijst van Nederlandsche Schaaldieren // Tijdschrift der Nederlandsche Dierkundige Vereeniging. Vol.1. P.22-269.

Makarov A.V. 1939. [About some new elements in the composition of fauna of Black Sea lagoons, in connection to ship traffic] // Dokladi AN SSSR. Vol.23. No.8. P.25-26 [in Russian].

Makarov Yu.N. 2004. [Fauna of Ukraine. Volume 26. Higher crustaceans. 1-2, Decapoda]. Kiev: Naukova Dumka. 429 p. [in Russian]

Makarevich P.R., Lyubin P.A., Larionov V.V. 2000. Basic tendencies in the structural dynamics of phytoplanktonic and benthic communities in the Sea of Azov // Russian Journal of Ecology. Vol.31. P.411-414

Marchand J., Saudray Y. 1971. Rhithropanopeus harrisii Gould tridentatus Maitland (Crustacé - Décapode. Brachyoure), dans le réseau hydrographique de l'ouest de 1'Europe en 1971 // Bulletin de la Société Linnéenne de Normandie. Vol.102. P.105-113.

Mariscal J.A.C., Garcia-Raso J.E., Gonzalez Gordillo J.I. 1991. Primera cita de Rhithropanopeus harrisii (Gould, 1841) (Crustacea, Decapoda, Brachyura, Xanthidae) en la Peninsula Iberica // Boletin del Instituto Espafiol Oceanografia. Vol.7. P.149-153.

Miljutin D.M. 2005. [Studies and census of commercial invertebrates of the upper sublittoral using SCUBA methods] // Methods of landscapes studies and stock assessment of bottom invertebrates and seaweed of the marine coastal zone. Moscow: Russian Federal Institute of Fishery and Oceanography (VNIRO) Publication. P.41-79 [in Russian].

Mizzan L., Zanella L. 1996. First record of Rhithropanopeus har risii (Gould, 1841) (Crustacea., Decapoda, Xanthidae) in the Italian Waters //Bollettino del Museo Civico di Storia Naturale di Venezia. Vol.46. P.109-122.

Mordukhay-Bolotovskoy F.D.1952. [About establishment of a new crab in the basin of river Don] // Priroda. No.1. P.20-21 [in Russian].

Nabozhenko M.V., Shokhin I.V., Bulysheva N.I. 2010. [Zoobenthos] // Matishov G.G., Boltachev A.R. (Eds.). The Introducers in the biodiversity and productivity of the Sea of Azov and the Black Sea. Rostov on Don: South Centre Russian Academy of Sciences. P.17-27 [in Russian].

Nebolsina T.K. 1959. [Crab in the Caspian Sea] // Priroda. No.6. P.32-33[in Russian].

Nesis K.N. 1956. [Bottom fauna of the Kerch Strait]. Diploma thesis. Moscow Technological Institute of Fishery Industry. Manuscript (deposited in the N.S. Gaevskaya Museum of Kaliningrad State Technical University) [in Russian].

Noël P. 2001. Le crabe américain Rhithropanopeus harrisii étendt-il actuellement son aire de distribution en Méditerranée? // Rapports de la Commission Internationale pour l'Exploration Scientifique de la Mer Méditerranée. Vol.36. P.407.

Nurkse K., Kotta J., Orav-Kotta H., Pärnoja M., Kuprijanov I. 2015. Laboratory analysis of the habitat occupancy of the crab Rhithropanopeus harrisii (Gould) in an invaded ecosystem: The north-eastern Baltic Sea // Estuarine, Coastal and Shelf Studies. Vol.154. P.152-157.

Olesen J., Tendal O.S. 2009. Amerikansk brakvandskrabbe - ny krabbeart etableret i Danmark // Dyrinaturog museum. Vol.2. P.26-28.

Petersen C. 2006. Range expansion in the northeast Pacific by an estuary mud crab - a molecular study // Biological Invasions. Vol.8. P.565-576.

Petrescu I., Balasescu A.-M. 1995. Contributions to the knowledge of Decapod fauna (Crustacea) from the Romanian coast of the Black Sea // Travaux du Muséum National d'Histoire Naturelle "Grigore Antipa". P.99-146.

Projecto-Garcia J., Cabral H., Schubart C.D. 2010. High regional differentiation in a North American crab species throughout its native range and invaded European waters: a phylogeographic analysis // Biological Invasions. Vol.12. P.253-263.

R Core Team. 2013. R: A language and environment for statistical computing. R Foundation for Statistical Computing, Vienna, Austria. http://www.R-project.org/ Accessed 1 October 2015
Revkov N.K., Bondarenko L.V., Grivtsov A.V. 2007. [Structure of the Malacostraca taxocen of Kruglaya Inlet (Southwestern Crimea, Black Sea)] // Ekologiya morya (Sevastopol). Vol.75. P.71-76 [in Russian].

Reznichenko O.G. 1967. [Transoceanic auto acclimatization of Rhithropanopeus harrisii: Crustacea, Brachyura)] // Trudy Instituta Okeanoligii AN SSSR. Vol. 85. P.136-177 [in Russian].

Roche D., Torchin M.E. 2007. Established population of the North American Harris mud crab, Rhithropanopeus harrisii (Gould 1841) (Crustacea: Brachyura Xanthidae) in the Panama Canal // Aquatic Invasions. Vol.2. P.155-161.

Ryan E.P. 1956. Observations on the life histories and the distribution of the Xanthidae (mud crabs) of Chesapeake Bay // American Midland Naturalist. Vol.56. No.1. P.138-162.

Selifonova Zh.P. 2012. Taxonomic composition and seasonal dynamics of the meroplankton in the coastal zone of the Northeastern Black Sea // Russian Journal of Marine Biology. Vol.38. P.1-9.

Sergeeva N.G., Burkatsky O.N. 2002. [Macrobenthos in eastern Azov Sea at the autumn of 2000] // Ekologiya morya (Sevastopol). Vol.61. P.29-35 [in Russian].

Shalovenkov N. 2005. Restoration of some parameters in the development of benthos after reduction of anthropogenous loading in the ecosystem of the Sevastopol Bay in the Black Sea // Mitigation and Adaptation Strategies for Global Change. Vol.10. P.105-113.

Skolka M., Preda C. 2010. Alien invasive species at the Romanian Black Sea coast - present and perspectives // Travaux du Muséum National d'Histoire Naturelle "Grigore Antipa". Vol.53. P.443-467.

Spiridonov V.A., Kolyuchkina G.A., Basin A.B., Kozlovsky V.V. 2016 (in press). Contemporary condition of macrozoobenthos in the ultra-shallow zone of the Taman Bay, Sea of Azov // Oceanology.

Tolley S.G., Brosious B.B., Peebles E.B. 2013. Recruitment of the crabs Eurypanopeus depressus, Rhithropanopeus harrisii, and Petrolisthes armatus to oyster reefs: the influence of freshwater inflow // Estuaries and Coasts. Vol.36. P.820-833.

Turoboyski K. 1973. Biology and ecology of the crab Rhithropanopeus harrisii ssp. tridentatus // Marine Biology. Vol.23. P.303-313.

Van der Velde G., Rajagopal S., Kelleher B., Musko I.B., Bij de Vaate A. 2000. Ecological impact of crustacean invaders: general considerations and examples from the Rhine River // Vaupel Klein J.C. von, Schramm F.R. (Eds.) The biodiversity crisis and Crustacea. Proceedings $4^{\text {th }}$ International Crustacean Congress. Amsterdam. The Netherlands. July 20-24. 1998. Rotterdam:Balkema. P.3-33.

Vinogradov A.K., Bogatova Yu.I., Sinegub I.A. 2012. [Aquatic ecosystems of marine ports of the Black Sea - Sea of Azov Basin (Introduction to ecology of marine ports)]. Odessa: Astroprint. 528 p. [in Russian].

Vorobyev V.P. 1949. [Benthos of the Sea of Azov] // Trudy AZCHERNIRO. Vol.13. P.1-195 [in Russian].

Vorstman A.G. 1939. Biologische Notizen betreffs der ZuiderseeKrabbe Pilumnopeus tridentatus (Maitland) syn. Heteropanope tridentate (Maitland). Mit einer mathematischen Bearbeitung des Materiales von A.W.H. van Herk // Bijdragen Dierkunde. Bd.27. S. 369-391.

Williams A.B. 1984. Shrimps, lobsters, and crabs of the Atlantic coast of the eastern United States, Maine to Florida. Washington, DC: Smithsonian Institution Press. 550 p.

Zalogin B.S., Kosarev A.N. 1999. [The Seas]. Moscow: Mysl. 399 p. [in Russian]

Zalota A.K., Spiridonov V.A., Tiunov A.V. 2013. The position of an invasive crab Rhithropanopeus harrisii in the food web of the Taman Bay, Sea of Azov // The $4^{\text {th }}$ Bi-annual Black Sea Conference: 28-31 October 2013, Constanta, Romania Black Sea - Challenges towards good environmental status. Abstracts book. Constanta: Editura Boldas. P.118.

Ziemiankowski V.L. 1951. Crabul Heteropanope tridentata (Maitland) si aparitia lui în complexul Razelm privită prin prisma economic-piscicolă // Buletinul Institutului de Cercetări Piscicole.Vol.10. No.4. P.67-72.

Responsible editor K.G. Mikhailov 